\title{
Modeling the remote and local connectivity of Antarctic krill populations along the western Antarctic Peninsula
}

\author{
Andrea Piñones ${ }^{1, *}$, Eileen E. Hofmann ${ }^{1}$, Kendra L. Daly ${ }^{2}$, Michael S. Dinniman ${ }^{1}$, \\ John M. Klinck ${ }^{1}$ \\ ${ }^{1}$ Center for Coastal Physical Oceanography (CCPO), Old Dominion University, 4111 Monarch Way, 3rd floor, Norfolk, \\ Virginia 23508, USA \\ ${ }^{2}$ College of Marine Science, University of South Florida, 140 Seventh Ave. South, St. Petersburg, Florida 33701, USA
}

\begin{abstract}
The abundance and distribution of Antarctic krill Euphausia superba over the western Antarctic Peninsula (wAP) continental shelf suggest that these populations are maintained by inputs from upstream sources via advection of individuals that originated in the Bellingshausen Sea, in addition to local spawning and retention. The objective of our study was to evaluate these 2 mechanisms (remote and local inputs) and the consequences for wAP Antarctic krill populations. The relative effect of local versus remote connectivity was investigated using Lagrangian particle tracking experiments. Particles released in the Bellingshausen Sea were transported to the wAP shelf in $120 \mathrm{~d}$, which is consistent with the time required for Antarctic krill eggs to develop into late-stage larvae. An estimated $23 \%$ of the particles released along the shelf break crossed the outer shelf and were transported to the mid and inner regions of the wAP shelf via 3 pathways that provide conduits for onshore intrusions of Circumpolar Deep Water (CDW). Of the particles that moved onto the wAP shelf, $54 \%$ were transported to inner shelf regions that are associated with areas of enhanced biological production. Of the particles at the outer shelf $\sim 33 \%$ continued transport northeastward with the Antarctic Circumpolar Current. Particles released in the mid and inner shelf showed limited connectivity and low export from the shelf $(<20 \%)$. The Lagrangian experiments indicate that Antarctic krill populations in the Marguerite Bay region of the wAP continental shelf are maintained by local and remote inputs of larvae. Regions influenced by intrusions of CDW are more dependent on remote inputs of Antarctic krill larvae.
\end{abstract}

KEY WORDS: Euphausia superba · Connectivity · Circulation · Lagrangian particles · Circumpolar Deep Water · Antarctic Peninsula

Resale or republication not permitted without written consent of the publisher

\section{INTRODUCTION}

The western Antarctic Peninsula (wAP) region of the Antarctic (Fig. 1) supports large and persistent populations of Antarctic krill Euphausia superba (Marr 1962, Atkinson et al. 2004, Deibel \& Daly 2007), which undergo seasonal variations in distribution (Siegel 1988, Siegel et al. 1997, 1998, Lascara et al. 1999). During austral spring and summer most gravid females of Antarctic krill migrate off- shore to the outer shelf and shelf break to spawn (Siegel 1988, 1992, Shaw 1997) (Fig. 2A). Immature adult and juvenile stages remain in coastal and shelf waters (Marr 1962, Hofmann et al. 1992, Lascara et al. 1999). Krill embryos released along the outer shelf are potentially entrained in the Antarctic Circumpolar Current (ACC), which flows along the outer shelf of the wAP (Orsi et al. 1995), and are transported downstream. The transport of krill larvae by the ACC provides a source of Antarctic krill 


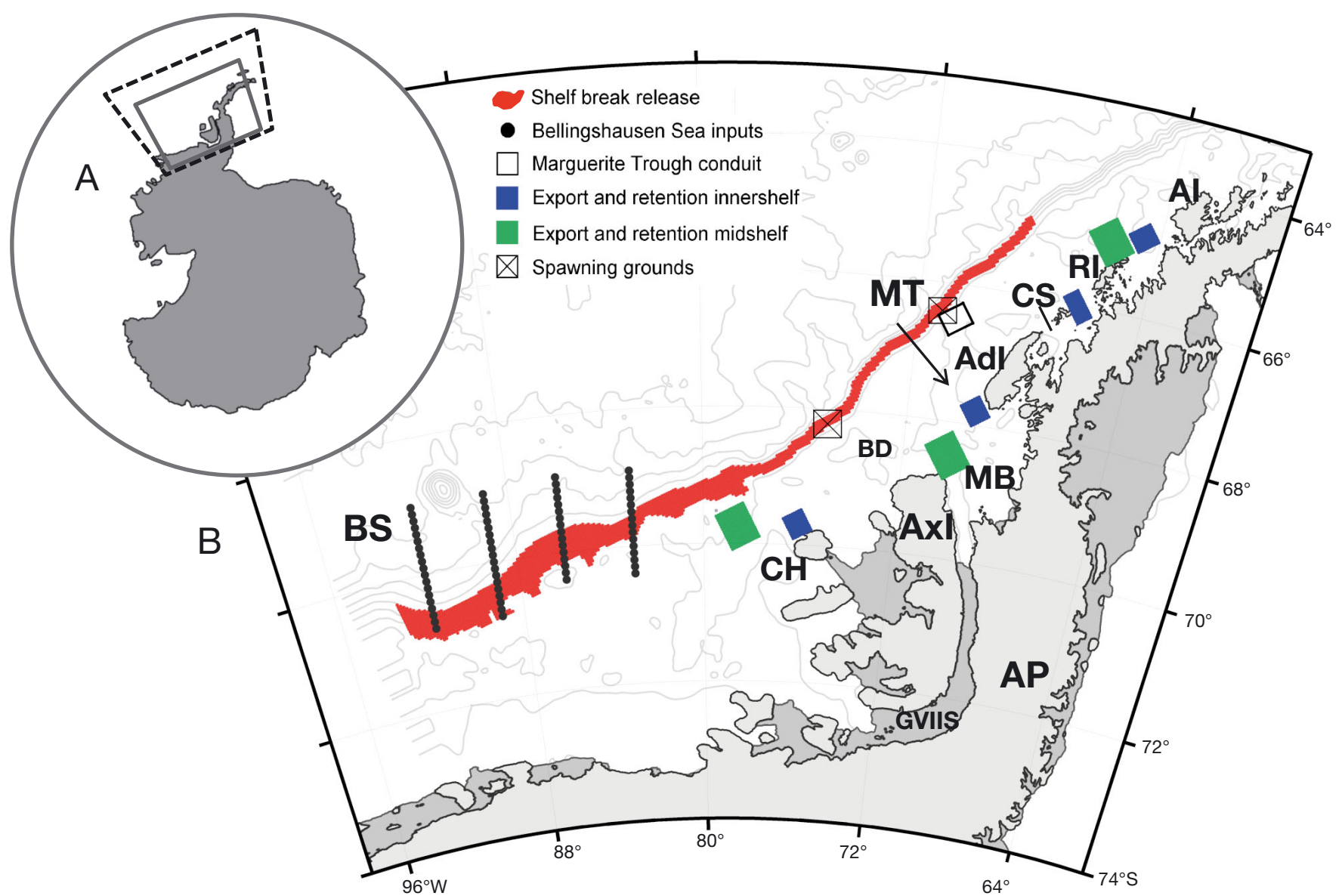

Fig. 1. (A) Map of Antarctica. Dashed line: circulation model domain. Solid gray line: study area. (B) Study area indicating the release locations for the Lagrangian particle experiments in the Bellingshausen Sea (•, across-shelf transects), along the shelf break (800 to $2000 \mathrm{~m}$ depth, red area), Marguerite Trough (open black square), mid-shelf (green squares), inner shelf (blue squares) and potential spawning grounds (squares with crosses). Thin gray lines: depth contours from 500 to 4500 m in 500 m intervals. AI: Anvers Island; RI: Renaud Island; CS: Crystal Sound; MT: Marguerite Trough; AdI: Adelaide Island; MB: Marguerite Bay; AxI: Alexander Island; GVIIS: George VI Ice Shelf; AP: Antarctic Peninsula; BS: Bellingshausen Sea; CH: Charcot Island; BD: Bathymetric Depression off AxI

to regions downstream from the wAP (e.g. Hofmann et al. 1998, Fach et al. 2002). During winter, the sea ice communities provide food resources for larval krill in coastal and shelf waters (Ross \& Quetin 1991, Frazer et al. 2002). Adult krill occupy a different depth in the water column, away from the sea ice surface (Fig. 2B) (Ross et al. 1996), and use different food resources and strategies to survive winter (Ikeda \& Dixon 1982, Quetin \& Ross 1991, Siegel 2005). This active seasonal migration produces a spatial separation of adults, juveniles and larvae (Quetin \& Ross 1984a, Siegel 2005, Nicol 2006).

The wAP shelf also has regions of enhanced biological production and retention (Huntley \& Brinton 1991, Costa et al. 2007, Piñones et al. 2011), which favor local growth, development and spawning of Antarctic krill (Brinton 1991, Quetin \& Ross 2003, Zhou et al. 2004). These regions, coupled with the deep shelf (400-500 m) and the presence of Circumpolar Deep Water (CDW), both of which are needed for successful Antarctic krill reproduction (Hofmann et al. 1992, Hofmann \& Hüsrevo lu 2003), provide potential spawning sites on the wAP shelf (Fig. 2). Krill embryos hatch at depth and the larvae return to the surface to begin feeding (Marr 1962, Marschall 1983, Quetin \& Ross 1984b). Spawning in areas where warm CDW is encountered shortens development time, which allows larvae to hatch at shallower depths, and have a shorter ascent to the surface.

The region of the wAP shelf around Marguerite Bay (Fig. 1B) was the focus for the US Southern Ocean Global Ocean Ecosystem Dynamics (SO GLOBEC) field studies during the austral fall and winter of 2001 and 2002. Characterization of the distribution and abundance of Antarctic krill was a primary focus for the SO GLOBEC field studies. Multi-frequency acoustic surveys (Lawson et al. 2008a) showed that 
fall-winter distributions of Antarctic krill were characterized by small, closely spaced aggregations, interspersed with large aggregations that accounted for the majority of the biomass (Lawson et al. 2008b). These aggregations were mostly located along the inner shelf (Lawson et al. 2008b), consistent with previous observations (Siegel 1989, Lascara et al. 1999). Zooplankton distributions obtained from video plankton recorder measurements (Ashjian et al. 2008) and net tows (Daly 2004, Ashjian et al. 2004, Wiebe et al. 2011) showed that larval krill were present over the SO GLOBEC study region. However, an across-shelf gradient in larval krill stage and relative abundance was observed, with relatively high abundances (up to 132 ind. $\mathrm{m}^{-3}$ ) of early-stage (calyptopis, furcilia 1 to 3 ) larval Antarctic krill occurring along the outer shelf and lower densities ( 1 to 25 ind. $\mathrm{m}^{-3}$ ) of primarily older furcilia (F4 to F6) stages occurring on the inner shelf (Daly 2004, K.L.D. unpubl. data). The German SO GLOBEC survey in the wAP region that occurred during April 2001 just prior to the US field study also showed higher abundances of krill larvae over the shelf break and slope offshore of Marguerite Bay (Pakhomov et al. 2004). These observations suggest that krill populations along the wAP region could have different source populations of larval krill.

Evidence for local spawning, recruitment and subsequent retention of krill on the wAP is suggested by length-frequency analysis of the krill in diets of Adélie penguins. Diet samples collected from wAP Adélie penguins showed a systematic increase in krill size that is consistent with the progression of distinct cohorts through the population with a 4 to $5 \mathrm{yr}$ periodicity (Fraser \& Hofmann 2003). This led to a hypothesis that the circulation gyres on the wAP shelf described by Stein (1992) and Smith et al. (1999) maintain a local krill population. Additional evidence for retention on the shelf is provided by an analysis of the size structure of the wAP Antarctic krill derived from 11 yr of net observations (Quetin \& Ross 2003), which also identified distinct cohorts. Inputs of larvae and juveniles from other regions that are then retained on the shelf can contribute to these cohorts. A sub-regional scale population genetic study for the Marguerite Bay region (Batta-Lona et al. 2011) showed small but significant differentiation among Antarctic krill from different areas of the wAP shelf. This genetic differentiation was interpreted as evidence of multiple sources of recruitment in the wAP region, as would occur for advective inputs from various regions and retention in shelf habitats.

Marrari et al. (2008) suggested connectivity between krill in the upstream Bellingshausen Sea and
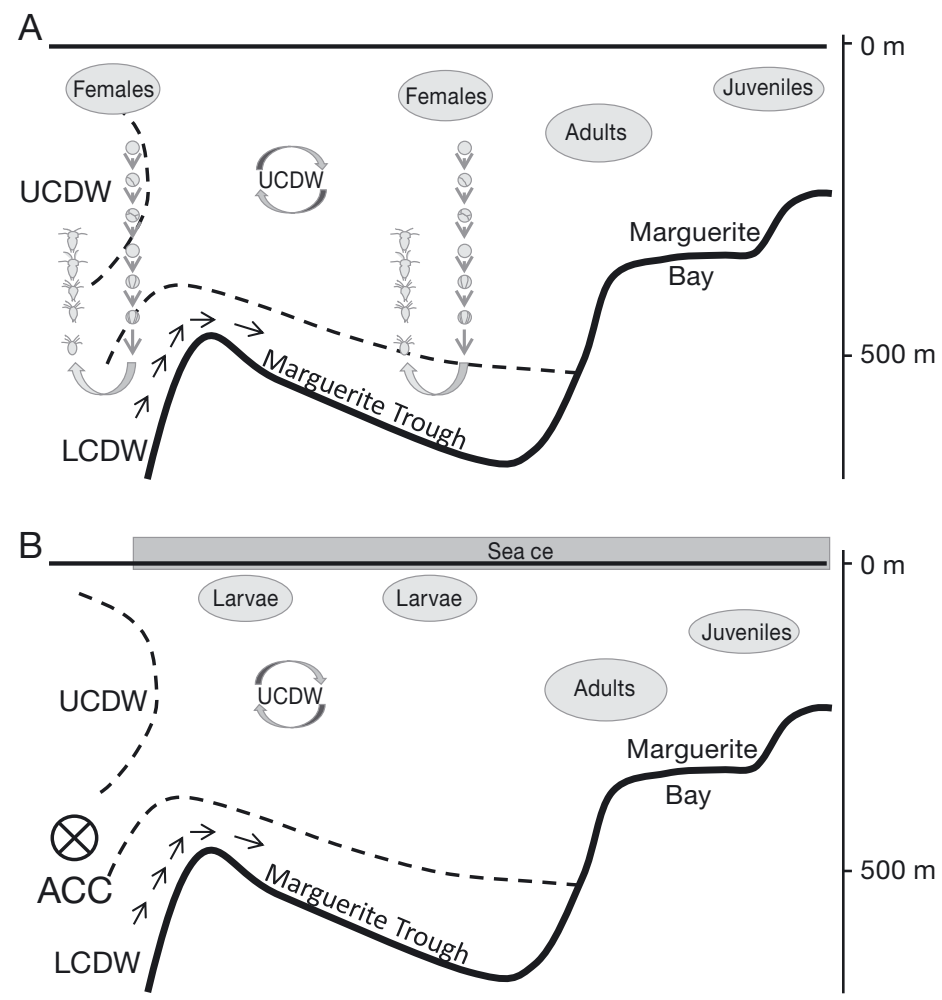

Fig. 2. Vertical distribution of Antarctic krill life stages across the Marguerite Trough region of the western Antarctic Peninsula (wAP) continental shelf in (A) summer and (B) winter. The relationship of the Antarctic krill descent-ascent reproductive cycle, which occurs during summer, with intrusions of Upper Circumpolar Deep Water (UCDW) and Lower Circumpolar Deep Water (LCDW) is indicated. The Antarctic Circumpolar Current (ACC) flows along the wAP shelf break. The circulation and hydrography distributions were modified from Moffat et al. (2009). $\otimes$ : current perpendicular to the plane of projection. The distribution of the Antarctic krill life

stages was modified from Siegel (2005) and Nicol (2006)

the krill population over the wAP shelf. These authors proposed that the high abundance (up to 132 ind. $\mathrm{m}^{-3}$ ) of krill larvae observed offshore of Marguerite Bay in fall 2001 could be, in part, attributed to female krill spawning in a region of high

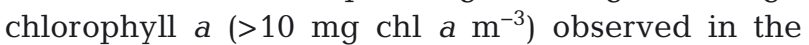
Bellingshausen Sea during the summer of 2001. Marrari et al. (2008) estimated that krill embryos spawned in the high chlorophyll a region would develop into larvae by the following fall ( $\sim \mathrm{mo})$. Advective velocities of $0.1 \mathrm{~m} \mathrm{~s}^{-1}$ (characteristic of ACC speeds) would result in the arrival of these krill larvae at the wAP outer shelf by fall.

The objectives of our study were to investigate the role of the circulation in providing local and remote inputs of krill to the wAP continental shelf and to determine the relative contribution of each to Antarctic krill populations of this region. To address these 
objectives, numerical Lagrangian particle tracking experiments were carried out for the region that extends from the western Bellingshausen Sea to the area north of the Antarctic Peninsula (Fig. 1).

\section{METHODS}

\section{Circulation model}

Lagrangian tracking experiments (Table 1) were used to simulate the passive transport of Antarctic krill larvae in the vicinity of the wAP. The Rutgers/ UCLA Regional Ocean Modeling System (ROMS) version 3.0 (Dinniman et al. 2011, Piñones et al. 2011) implemented for the wAP region (Fig. 1B) provided the circulation distributions for the Lagrangian tracking simulations. This model is a free-surface, terrainfollowing, primitive equations ocean circulation model (Haidvogel et al. 2008, Shchepetkin \& Mc Williams 2009). The model domain extends along the western side of the Antarctic Peninsula from $72^{\circ} \mathrm{S}$ to just past the tip of the Antarctic Peninsula, covers the entire continental shelf and extends $\sim 500 \mathrm{~km}$ offshore from the shelf break (Fig. 1B). The model domain covers the continental shelf region in and around Marguerite Bay, has a $4 \mathrm{~km}$ horizontal resolution, and is composed of 24 vertical sigma-layers that concentrate toward the surface and the bottom. The model is forced by surface fluxes such as heat, momentum (wind stress) and freshwater (imposed as a salt flux), and is dynamically forced by the ACC, the southern boundary of which flows along the wAP shelf break. The circulation model includes a dynamic sea-ice model (Budgell 2005) and thermodynamically active ice shelves (Dinniman et al. 2007).

The model bathymetry grid was constructed from sources that include Woods Hole Oceanographic
Institution SO GLOBEC bathymetry data (Bolmer 2008), ETOPO2v2 (2 minute gridded bathymetry; Smith \& Sandwell 1997), BEDMAP data including bathymetry beneath ice shelves and ice thickness (Lythe et al. 2001), a bathymetry developed for simulation of tidal flow under ice shelves (Padman et al. 2002), and thickness and bedrock depth below sea level for the George VI Ice Shelf (Maslanyj 1987).

Monthly climatologies derived from the Simple Ocean Data Assimilation (SODA) reanalysis (Carton \& Giese 2008) were used to specify temperature, salinity and depth-averaged velocities at the model boundaries (Dinniman \& Klinck 2004). The model was forced with daily wind stress and wind speed calculated from $12 \mathrm{~h}$ winds obtained from the Antarctic Mesoscale Prediction System (AMPS) (Powers et al. 2003), and were applied as a surface stress. The wind forcing was for 15 September 2003 to $15 \mathrm{Sep}$ tember 2005. Freshwater and air-sea fluxes were computed using clouds from the International Satellite Cloud Climatology Project (ISCCP) and daily winds and monthly climatologies of precipitation, surface pressure, air temperature and humidity were obtained from AMPS. More details of the wAP circulation model are given in Dinniman et al. (2011).

\section{Lagrangian particle tracking}

The ocean circulation model provided current fields ( $u, v$ and $w$ components of the flow) that were used to simulate the trajectory followed by a particle $(\vec{X})$ in space $(x, y, z)$ and time $(t)$, described as:

$$
\frac{\mathrm{d} \vec{X}}{\mathrm{~d} t}=\vec{U}(\vec{X}, t)+W_{v w} \hat{Z}+W b \hat{Z}
$$

where $\frac{\mathrm{d} \vec{X}}{\mathrm{~d} t}$ is the change of the location of the

Table 1. Experimental set, regions, number, depths, and time and frequency at which particles were released for the Lagrangian particle tracking simulations

\begin{tabular}{|c|c|c|c|c|}
\hline Set & Release region & $\begin{array}{l}\text { Number of } \\
\text { release points }\end{array}$ & Depth of release $(\mathrm{m})$ & Time and frequency of release \\
\hline 1 & $\begin{array}{l}\text { Bellingshausen } \\
\text { Sea }\end{array}$ & 70 & $\begin{array}{c}0,25,50,100,125,150,175 \\
200,250,300,350\end{array}$ & 24 December to 12 February; every $10 \mathrm{~d}$ \\
\hline 1 & Shelf break & 2358 & $50,150,300$ & $\begin{array}{l}24 \text { December, } 29 \text { December, } 18 \text { January, } \\
2 \text { February, } 27 \text { February; every day }\end{array}$ \\
\hline 2 & Marguerite Trough & 120 & $25,100,200,300,500$ & 24 December to 24 January; every day \\
\hline 3 & Mid-shelf & 624 & $50,100,150,300$ & 24 December; one day \\
\hline 3 & Inner-shelf & 360 & $25,50,100,300$ & $\begin{array}{l}15 \text { November, } 24 \text { December, } 13 \text { January } \\
\text { every day }\end{array}$ \\
\hline
\end{tabular}


particle in the 3-dimensional field with time. The location is modified by the advective velocity field $(\vec{U}(\vec{X}, t))$, obtained from the circulation model, and vertical diffusivity, which was included by adding a vertical random walk to the particle location, and diurnal vertical migration. The random vertical displacement $\left(W_{V W}\right)$ and diurnal vertical migration of Antarctic krill larval stages $(W b)$ were added to the vertical $(\hat{Z})$ particle location at each time step (Hunter et al. 1993, Visser 1997).

The numerical integration for the Lagrangian circulation was performed using a fourth-order Milne predictor (Abramowitz \& Stegun 1964) and a fourth-order Hamming corrector scheme (Hamming 1973). A forward difference scheme was used when vertical displacement resulting from vertical walk parametrization was estimated. The vertical displacement has a Gaussian probability distribution and there is a correction for the vertical gradient in the diffusion coefficient. A 4 min integration time was used for the Lagrangian particles, which is the same as the baroclinic integration time, and the location of each particle was obtained at $12 \mathrm{~h}$ intervals. This time interval was smaller than the temporal decorrelation scales for the circulation on the wAP continental shelf (Piñones et al. 2011). At $4 \mathrm{~km}$ horizontal resolution, the model has difficulty resolving small mesoscale eddies $(\sim 10 \mathrm{~km}$ scale) that can be created on the wAP shelf and lead to some unresolved horizontal dispersion of the parti-

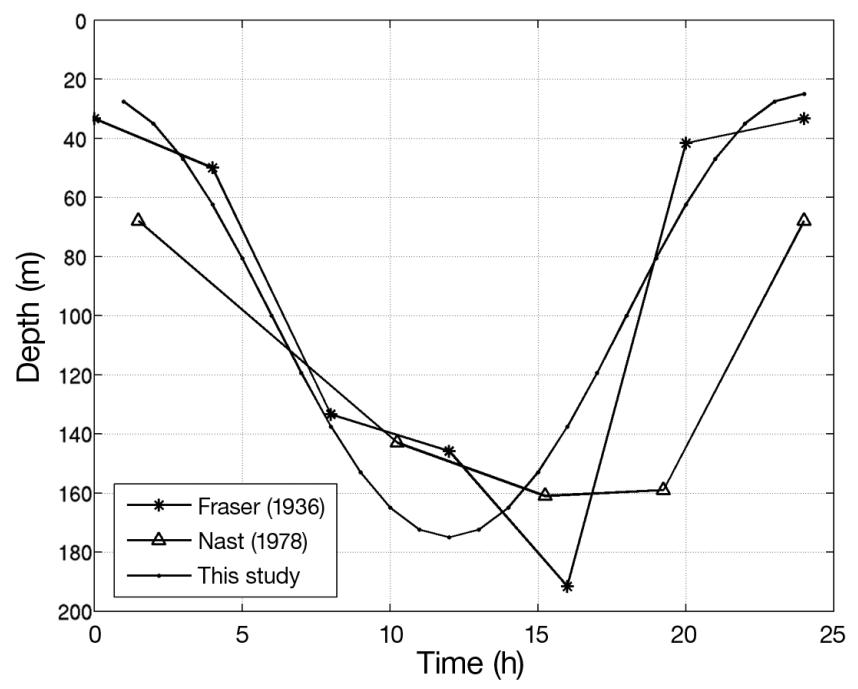

Fig. 3. Mean depth-time distribution of Antarctic krill larvae (stages calyptopis 2 to furcilia 6) obtained from net-based observations given in Fraser (1936) and Nast (1978). The vertical distribution obtained from Eq. (2), which was used with the Lagrangian particle tracking experiments, is shown for comparison cles. The mesoscale eddies that have been observed within troughs on the wAP shelf (where much of the shelf particle transport is occurring) are 6 to $10 \mathrm{~km}$ in diameter and occur with a frequency of 4 events per month (Moffat et al. 2009, Martinson \& McKee 2012). However, these eddies have low cross-stream velocities $\left(1-5 \mathrm{~cm} \mathrm{~s}^{-1}\right.$; Moffat et al. 2009) compared with the modeled and observed mean advective currents $\left(\sim 10-20 \mathrm{~cm} \mathrm{~s}^{-1}\right)$ and thus they are not a significant missing source of particle dispersion.

\section{Diurnal vertical migration}

Fraser (1936) described the vertical distribution and migration for early life stages of Antarctic krill, which showed that larvae reached $1000 \mathrm{~m}$ but the highest abundances were found between the surface and $250 \mathrm{~m}$ (Fig. 3). Observations based on net tows made south of Elephant Island at the northern tip of the Antarctic Peninsula showed an increase in vertical displacement with advancing larval development (Nast 1978). At night, krill larvae (calytopis 3 to furcillia 6$)$ were concentrated near the surface $(\sim 70 \mathrm{~m})$ and were near $180 \mathrm{~m}$ during the day (Fig. 3). To assess the sensitivity of the Lagrangian simulations to vertical displacements that result from biological behaviors, a vertical velocity of the larvae was added to Eq. (1). The diurnal vertical displacement of the larvae $\left(Z_{W}\right)$ is described by a sinusoidal function of the form:

$$
Z W=A \cos (\omega T)
$$

where $A$ is the amplitude of the displacement in meters (Fig. 3), $\omega$ is the frequency of the diurnal cycle $\left(\mathrm{s}^{-1}\right)$ and $T$ is the integration time used for the Lagrangian calculation.

\section{Antarctic krill larval development time}

Antarctic krill develop from an egg through 12 larvae stages that include nauplius (2 stages), metanauplius, calyptosis (3 stages) and furcilia (6 stages) (Fraser 1936). Development times obtained from modeling studies (Hofmann et al. 1992, Hofmann \& Lascara 2000), laboratory experiments (Ikeda 1984) and field observations (Witek et al. 1980, Ross et al. 1988, Daly 1990) were used to define a time interval for each larval stage and the median of these was used to set the time span for the Lagrangian simulations (Table 2). 
Table 2. Cumulative developmental time (d) for krill larvae obtained from laboratory experiments (Ikeda 1984), field data analysis (Witek et al. 1980, Ross et al. 1988, Daly 1990) and modeling studies (Hofmann et al. 1992, Hofmann \& Lascara 2000). The modelderived development times are representative of average conditions. The range of days and the median time associated with each developmental stage is given in the last 2 rows. Krill life stages: $\mathrm{N}=$ nauplius (stages 1 to 2 ); $\mathrm{MN}=$ metanauplius; $\mathrm{C}=$ calyptopis (stages $1-3) ; \mathrm{F}=$ furcilia (stages 1-6)

\begin{tabular}{|c|c|c|c|c|c|c|c|c|c|c|c|c|}
\hline N1 & N2 & $\mathrm{MN}$ & $\mathrm{C} 1$ & $\mathrm{C} 2$ & $\mathrm{C} 3$ & F1 & $\mathrm{F} 2$ & F3 & F4 & F5 & F6 & \\
\hline- & - & - & 30 & $45-60$ & $60-75$ & $70-90$ & 75-105 & $90-120$ & $105-135$ & $120-180$ & $135-240$ & Witek et al. $(1980)^{\mathrm{a}}$ \\
\hline- & $14-24$ & $22-41$ & 38 & 52 & - & - & - & - & - & - & - & Ross et al. (1988) \\
\hline - & - & - & - & - & - & - & - & $90-121$ & $95-135$ & $118-164$ & $114-193$ & Daly $(1990)^{a, b}$ \\
\hline $5-8$ & - & $10-16$ & $18-33$ & $33-45$ & - & - & - & - & - & - & - & Hofmann et al. $(1992)^{\mathrm{C}}$ \\
\hline 7 & 19 & 26 & 28 & 47 & 63 & 74 & 88 & 103 & 115 & 146 & 186 & Median \\
\hline
\end{tabular}

\section{Lagrangian simulations}

Three sets of numerical Lagrangian experiments were conducted to determine the role of ocean circulation on the connectivity of Antarctic krill populations along the WAP (Fig. 1B, Table 1). The first set was designed to test the potential for krill embryos spawned in the Bellingshausen Sea and along the shelf break to reach the wAP continental shelf. This set included 2 series of releases. The first examined connection with the Bellingshausen Sea, and particles were released along 4 transects $\left(83^{\circ} \mathrm{W}\right.$, $85^{\circ} \mathrm{W}, 89^{\circ} \mathrm{W}$ and $92^{\circ} \mathrm{W}$ ) that extended seaward across the shelf break (Fig. 1B). The release locations coincided with observed high chlorophyll a concentrations (Marrari et al. 2008), and included the region suggested as a source area for the krill larvae observed offshore of Marguerite Bay (Daly 2004). The contribution from the Bellingshausen Sea was estimated using the percentage of particles entrained in the continental shelf $(800 \mathrm{~m}$ isobath as boundary) of the wAP.

Particles were released at 25 to $50 \mathrm{~m}$ intervals between 0 and $350 \mathrm{~m}$ at $10 \mathrm{~d}$ intervals between $24 \mathrm{De}$ cember and 12 February (Table 1), which corresponds to the period of peak krill spawning in this region of the Antarctic (Spiridonov 1995). Trajectories of particles that moved onto the WAP in the vicinity of Alexander Island and Marguerite Bay provided estimates of potential connectivity of the WAP and upstream regions. All these 2 sitesintrusions of CDW occur (e.g. Fig. 11 in Dinniman \& Klinck 2004) and have persistent onshelf flow. Transport times were mapped to development times for several larval stages, assuming normal development (Table 2), and this was used to identify possible origination regions or krill spawning grounds. Particles were also released along the shelf break at every circulation model grid point (every $4 \mathrm{~km}$ ) west of $65^{\circ} \mathrm{W}$ between the 800 and $2000 \mathrm{~m}$ isobaths (Fig. 1B) at 50, 150 and $300 \mathrm{~m}$ at 5 times between 24 December and 27 February (Table 1). The contribution of the shelf break release to the Marguerite Bay region was determined using the percentage of the particles that entered the Marguerite Bay region.

The second set of numerical Lagrangian experiments was designed to examine the role of Marguerite Trough as a conduit for onshelf transport of particles. A high-resolution array of particles was released at the intersection of the trough with the shelf break (Fig. 1B). Particles were released at $1 \mathrm{~d}$ intervals for $32 \mathrm{~d}$ between 25 and $500 \mathrm{~m}$ (Table 1). The number of particles following particular pathways was calculated and used to determine dominant transport pathways.

The third set of experiments was designed to explore local retention and export of krill larvae, and included mid- and inner-shelf releases (Table 1). Particles were released between 0 and $300 \mathrm{~m}$ over the mid-shelf west of Charcot Island, the western entrance of Marguerite Bay along the trough, and north of Renaud Island (Fig. 1B). These areas correspond to regions where high krill abundance has been observed. Export from the shelf was defined as the number of particles that crossed the $800 \mathrm{~m}$ isobath, which is the outer shelf edge (Bolmer 2008).

Connectivity along the inner shelf was investigated by releasing particles at several depths (Table 1) close to shore near Charcot Island, Adelaide Island, Renaud Island and Anvers Island (Fig. 1B) on 15 November, 24 December and 13 January. These times correspond to peak spawning periods over the wAP continental shelf 
(Ross \& Quetin 1986, Spiridonov 1995). The surface distribution of furcilia 6 larvae was determined and the number of these larvae in regions of the wAP with equal surface area (e.g. $40 \mathrm{~km}^{2}$ ) was calculated. The particle counts provided a measure of the connectivity and export from the 4 sites to other parts of the shelf.

\section{RESULTS}

\section{Diurnal vertical migration}

The effect of diurnal vertical migration on particle trajectories and transport pathways was assessed by comparing simulation results obtained with and without active migration (Fig. 4). The trajectories from the Marguerite Trough simulations were used for the comparison and are representative of the results obtained from the other numerical experiments. The percentage difference (Fig. 4) in the trajectories followed by the particles with and without vertical migration was $<10 \%$ along the dominant transport pathways for all release depths. For particles released below $100 \mathrm{~m}$ the difference is $<5 \%$. The monthly mean of the percentage of particles with and without vertical migration that followed various pathways was estimated and compared using a $t$ test, which indicated that the means were statistically
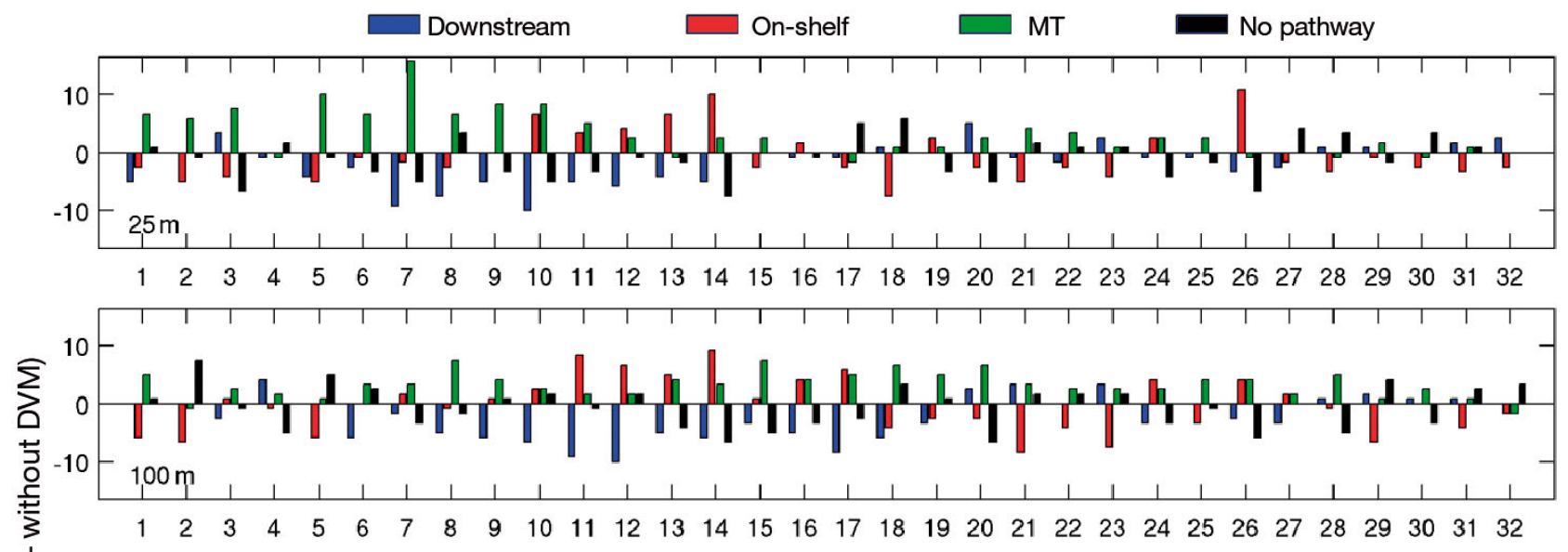

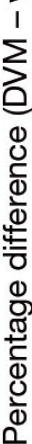

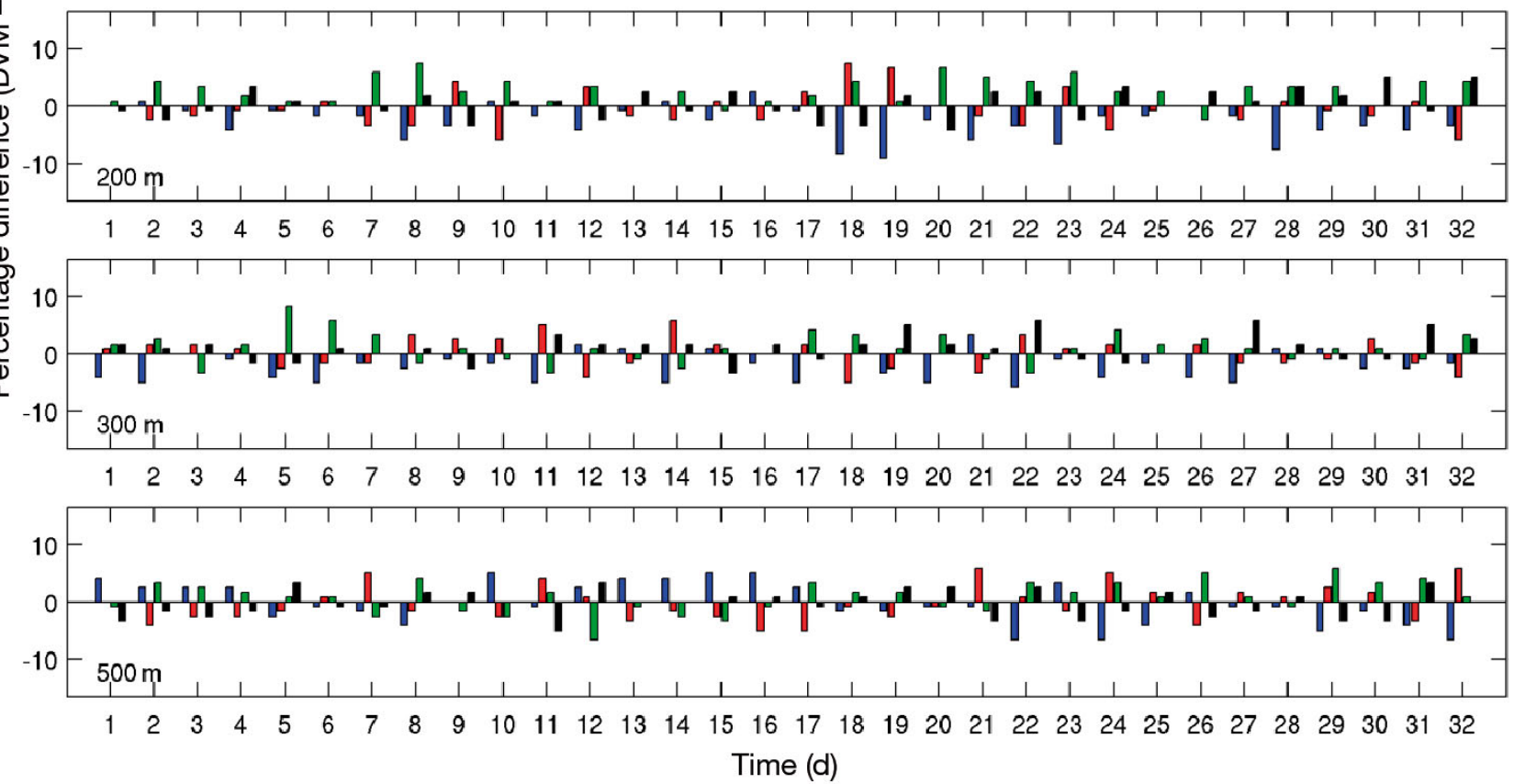

Fig. 4. Percent difference between simulated particle trajectories (following the 3 dominant pathways) that included diurnal vertical migration and simulations without diurnal vertical migration (DVM) for releases at 25, 100, 200, 300 and $500 \mathrm{~m}$ depth. The simulations used for the comparisons are from particles released at the outer end of Marguerite Trough (MT) at $100 \mathrm{~m}$ depth (see Fig. 9). The percentage of particles that followed no pathway is also shown 

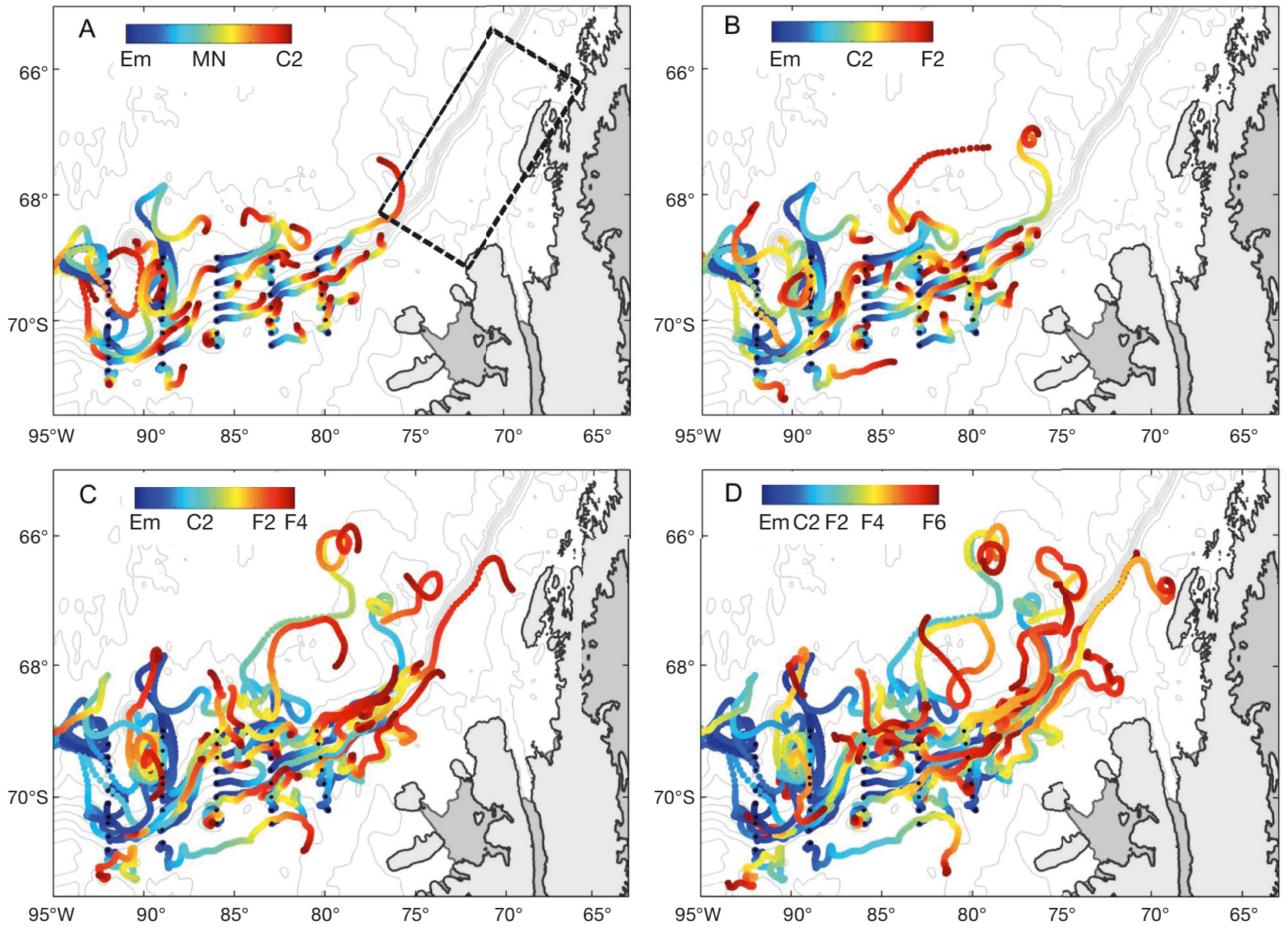

Fig. 5. Transport pathways of particles released at $25 \mathrm{~m}$ depth in the Bellingshausen Sea after (A) $47 \mathrm{~d}$, (B) $88 \mathrm{~d}$, (C) $115 \mathrm{~d}$ and (D) $186 \mathrm{~d}$. Transport time was mapped to development time to show the distribution of the calyptopis 2 (C2; A), furcilia 2 (F2; $\mathrm{B})$, furcilia $4(\mathrm{~F} 4 ; \mathrm{C})$ and furcilia 6 (F6; D) larval stages. The individual trajectories show the developmental progression for the particular stage. The US SO GLOBEC study region is shown in A (dashed rectangle). See Fig. 1 for geographic locations. Early life stages of krill are abbreviated as: Em = embryo; $\mathrm{MN}=$ metanauplius

equal at a $95 \%$ significance level. Differences in the horizontal dispersion of the vertically migrating particles were small, as demonstrated in a later section. Overall, vertical migration does not significantly influence the vertical and horizontal particle dispersion or general transport patterns because flow velocities on the wAP shelf are typically $<0.05 \mathrm{~m} \mathrm{~s}^{-1}$ and vertical gradients are weak (Dinniman \& Klinck 2004, Piñones et al. 2011). Thus, the results presented in the following sections are based on the particle trajectories without diurnal vertical migration.

\section{Bellingshausen Sea and shelf break inputs}

Particles released near the surface (Fig. 5) and at depth (Fig. 6) in the Bellingshausen Sea were transported to the northeast with the prevailing flow of the
ACC or moved further off-shelf and retained in the region. The trajectories showed considerable meandering, especially in the off-shelf region.

The trajectories associated with the calyptopis 2 stage (Fig. 5A) reached the outer portion of the wAP towards the end of its developmental time. On-shelf movement of this developmental stage occurred upstream of the US SO GLOBEC study region. Similarly, the furcilia 2 stage (Fig. 5B) was transported onto the shelf upstream of this area. Particle trajectories associated with furcilia 4 (Fig. 5C) and furcilia 6 (Fig. 5D), however, moved onto the wAP in the region of Marguerite Trough and off of Alexander Island. The furcilia 6 trajectories reached the inner wAP shelf just off of Adelaide Island (Fig. 5D). The trajectories for the particles released at $125 \mathrm{~m}$ showed transport patterns that were similar to those of the surface particles (Fig. 6). The older furcilia 

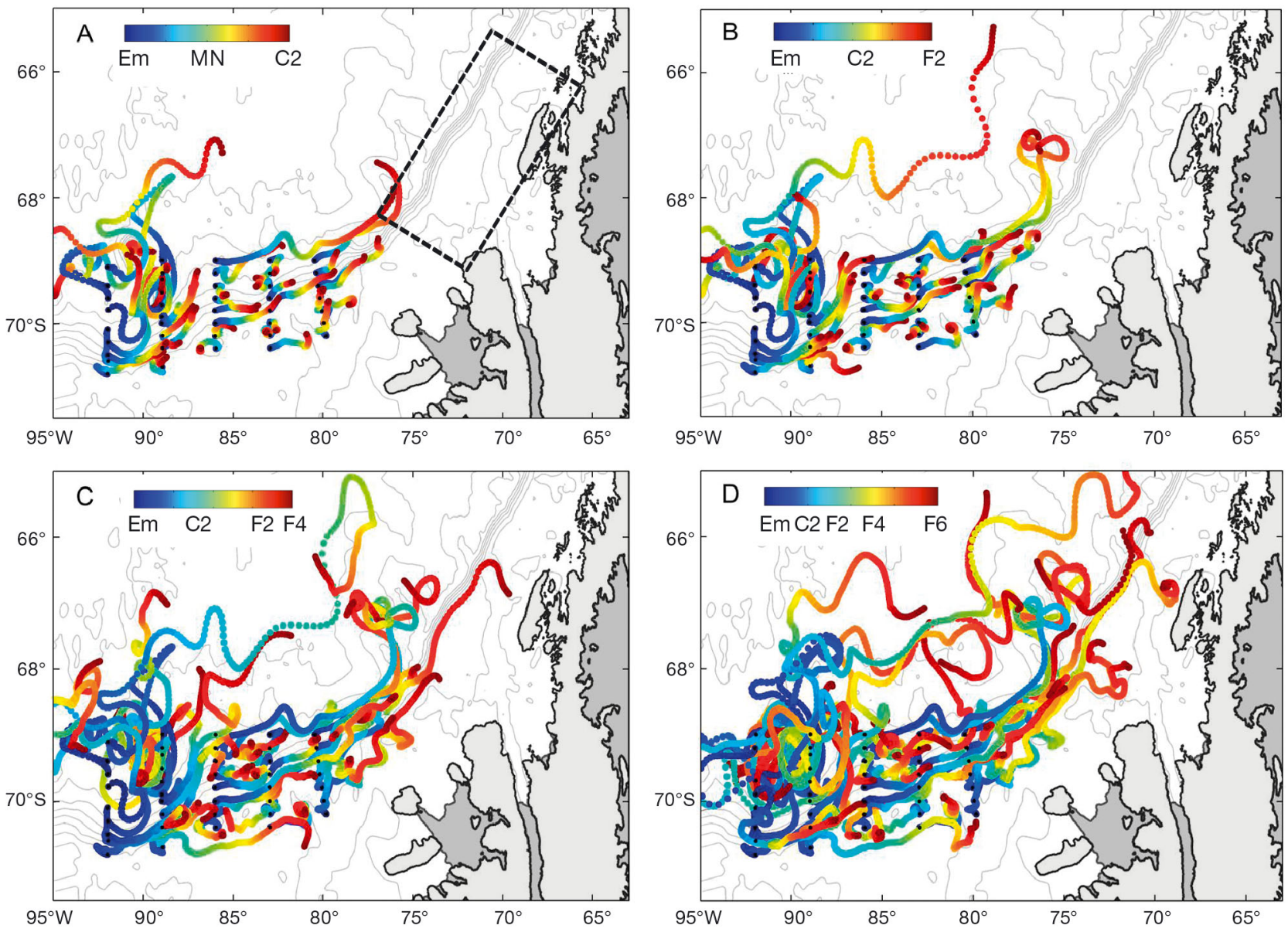

Fig. 6. Transport pathways of particles released at $125 \mathrm{~m}$ depth in the Bellingshausen Sea after (A) $47 \mathrm{~d}$, (B) $88 \mathrm{~d},(\mathrm{C}) 115 \mathrm{~d}$, and (D) $186 \mathrm{~d}$. Transport time was mapped to development time to show the distribution of the calyptopis 2 (C2; A), furcilia 2 (F2; B), furcilia $4(\mathrm{~F} 4 ; \mathrm{C})$ and furcilia 6 (F6; D) larval stages. The individual trajectories show the developmental progression for the particular stage. The US SO GLOBEC study region is shown in A (dashed rectangle). Early life stages of krill are abbreviated as: $\mathrm{Em}=$ embryo; $\mathrm{MN}=$ metanauplius

stages were transported onto the WAP continental shelf in the Marguerite Bay region.

The percentage of furcilia 4 and 6 larvae released in the upper $25 \mathrm{~m}$ that was transported onto the continental shelf was 4 to $7 \%$ (Fig. 5C,D, Table 3). The percentage of older larvae provided to the shelf increased with depth (Fig. 6). Also, the releases at depths greater than $100 \mathrm{~m}$ resulted in more of the younger larval stages (younger than calyptopis 2) moving onto the continental shelf. The maximum percentage of larvae that moved onto the shelf occurred between 150 and $200 \mathrm{~m}$ for all larval stages (Table 3).

Embryos spawned in the Bellingshausen Sea potentially reach the continental shelf along the wAP as different stages of development (Table 3). Of these embryos, $\sim 15$ to $25 \%$ reach the Marguerite Bay area as 1 -yr-old krill. The input of larvae at any develop-
Table 3. Percentage of different krill larvae developmental stages that originated in the Bellingshausen Sea that were transported onto the western Antarctic Peninsula continental shelf at different depths. The mean for all depths is shown. See Table 2 for larval stage abbreviations

\begin{tabular}{|c|c|c|c|c|c|}
\hline \multirow{2}{*}{$\begin{array}{l}\text { Depth } \\
\text { (m) }\end{array}$} & \multicolumn{5}{|c|}{ - Larval stage } \\
\hline & $\mathrm{C} 2$ & $\mathrm{~F} 2$ & F4 & F6 & $1 \mathrm{yr}$ old \\
\hline 0 & 0.6 & 2.3 & 3.5 & 6.4 & 11.4 \\
\hline 25 & 3.2 & 5.3 & 6.1 & 7.3 & 12.3 \\
\hline 50 & 4.7 & 6.7 & 7.6 & 11.1 & 16.1 \\
\hline 100 & 7.0 & 10.2 & 13.2 & 16.7 & 21.1 \\
\hline 125 & 7.9 & 11.4 & 12.9 & 16.1 & 21.9 \\
\hline 150 & 8.8 & 12.9 & 15.2 & 18.4 & 26.6 \\
\hline 175 & 10.5 & 13.7 & 15.5 & 18.4 & 26.3 \\
\hline 200 & 9.1 & 13.5 & 15.8 & 18.4 & 24.9 \\
\hline 250 & 8.5 & 10.8 & 13.1 & 17.5 & 22.5 \\
\hline 300 & 6.4 & 7.6 & 9.9 & 12.6 & 20.5 \\
\hline 350 & 4.1 & 7.9 & 9.6 & 13.7 & 19.3 \\
\hline Mean & 6.4 & 9.3 & 11.1 & 14.2 & 20.3 \\
\hline
\end{tabular}




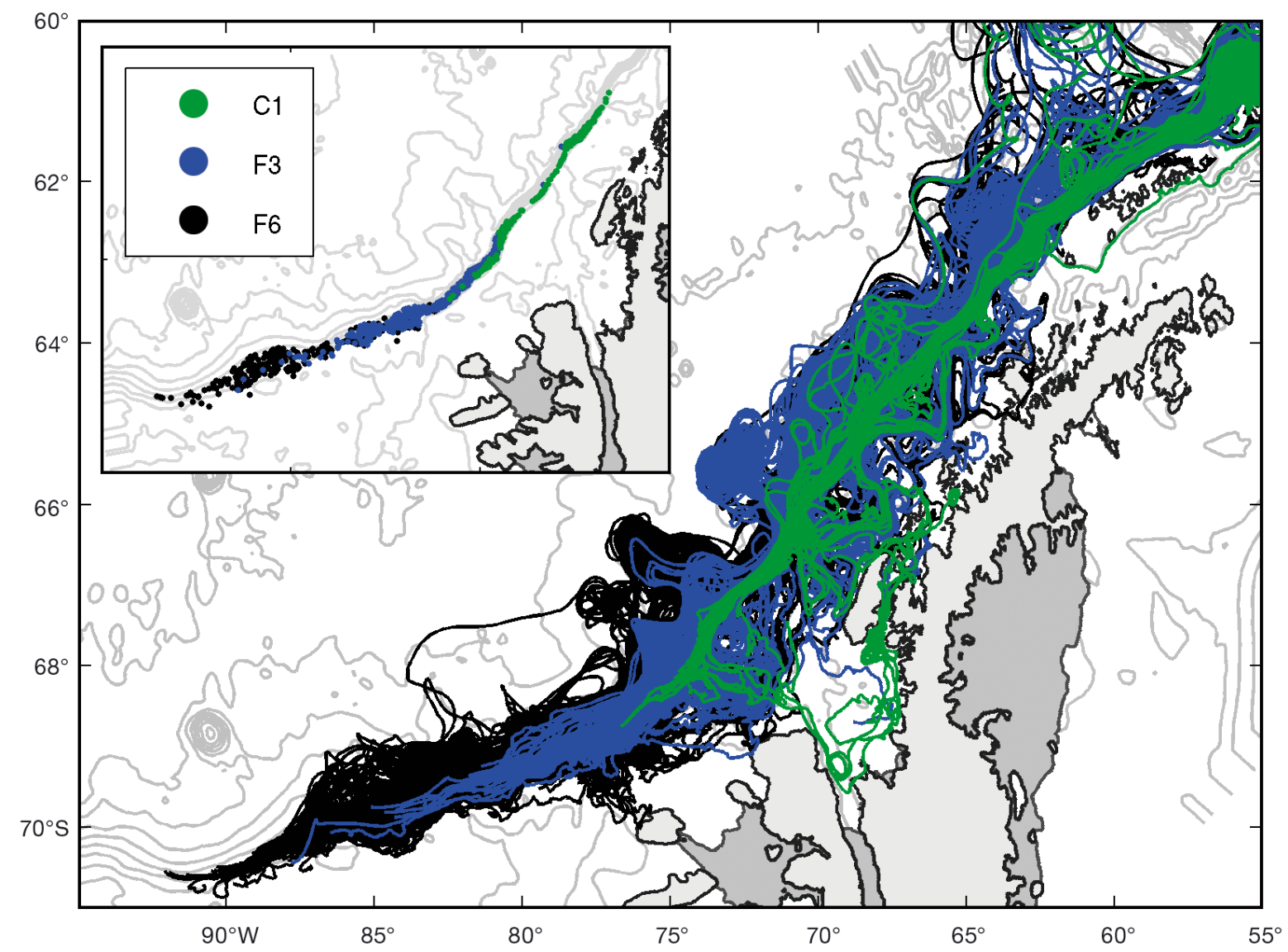

Fig. 7. Origination regions (inset) and simulated trajectories for particles released along the shelf break. The origination regions represent particles that entered the Marguerite Bay shelf region as calyptopis 1 ( $\mathrm{C} 1$; green circles and trajectories), furcilia 3 (F3; blue circles and trajectories) and furcilia 6 (F6; black circles and trajectories). The developmental stage was determined by mapping particle transit time to larval stage using the developmental times given in Table 2

mental stage occurs between 0 and $350 \mathrm{~m}$, but is at a maximum between 150 and $200 \mathrm{~m}$ (Table 3).

Particles released along the shelf break showed that all depths (50, 150 and $300 \mathrm{~m}$ ) provided krill larvae to the continental shelf around Marguerite Bay (Fig. 7, Table 4). Of the krill embryos spawned along the wAP shelf break, $\sim 7$ to $10 \%$ entered the Marguerite Bay shelf region as early calyptopis (Fig. 7), and between 18 and $26 \%$ reached the shelf as furcilia 6 (Fig. 7). Late furcilia source regions were farther west of the Marguerite Bay region $\left(\sim 90^{\circ} \mathrm{W}\right)$ and had input percentages that were similar to those obtained from the Bellingshausen Sea simulations. The particle transport pathways (Fig. 7) showed 2 preferred sites for intrusions onto the shelf independent of the depth or date of release: the depression off Alexander Island and the intersection of Marguerite Trough with the shelf break. These are areas where CDW intrusions occur (Dinniman \& Klinck 2004, Klinck et al. 2004).
The particles that moved onto the shelf at these sites were tracked back to their source regions and the transport time was converted to developmental time for the calyptopis 2 and furcilia stages (Fig. 8). The 3 larval stages that arrived at the Alexander Island location originated mostly along the shelf break, either near the bathymetric depression, for the calyptopis 2 stage, or further west $\left(\sim 90^{\circ}\right)$, for the late furcilia stages (Fig. 8A). Some of the calyptopis and furcilia 2 and 3 larvae originated offshore of the Alexander Island depression. The origination regions for the larvae observed in the Marguerite Trough area were more widely distributed (Fig. 8B). Some of the particles originated along the shelf break, but a large portion also came from the region off the shelf offshore of Marguerite Bay. Most of the calyptopis 2 and early furcilia larvae observed in the Marguerite Trough intersection derived from the region along and across the shelf break in an area east of $80^{\circ} \mathrm{W}$ (Fig. 8B). In contrast, most of the late furcilia stages 
Table 4. Percentage of different krill larvae developmental stages that originated along the shelf break that were transported onto the western Antarctic Peninsula shelf near Marguerite Bay at different depths for releases between 29 December 2003 and 2 February 2004. The mean for all depths is shown. See Table 2 for larval stage abbreviations

\begin{tabular}{|lrrrr|}
\hline \multirow{2}{*}{ Release day } & \multirow{2}{*}{$\begin{array}{c}\text { Depth } \\
(\mathrm{m})\end{array}$} & \multicolumn{4}{c|}{ Larval stage } & \multirow{2}{*}{ C1 } & F3 & F6 \\
\cline { 3 - 5 } & & & & \\
29 December & 50 & 7.7 & 14.1 & 20.5 \\
29 December & 150 & 7.0 & 13.7 & 21.1 \\
29 December & 300 & 7.4 & 14.4 & 22.0 \\
13 January & 50 & 10.0 & 14.7 & 22.2 \\
13 January & 150 & 10.9 & 18.2 & 24.8 \\
13 January & 300 & 10.6 & 17.4 & 23.7 \\
2 February & 50 & 8.7 & 12.6 & 17.8 \\
2 February & 150 & 8.4 & 14.9 & 25.1 \\
2 February & 300 & 9.3 & 16.8 & 25.7 \\
Mean & all & 8.9 & 15.2 & 22.5 \\
\hline
\end{tabular}

came from the area west of $80^{\circ} \mathrm{W}$ along the shelf break and offshore between 3000 and $4000 \mathrm{~m}$.

The depth distribution of the larvae arriving on the shelf via either the Alexander Island depression or the Marguerite Trough intersection differed for the 2 regions. At the Alexander Island depression, the highest percentage $(\sim 40 \%)$ of the larvae was observed at $400 \mathrm{~m}$ (Fig. $8 \mathrm{C}$ ). The percentage of particles arriving at the combined depths of 100 and $200 \mathrm{~m}$ was higher $(\sim 46 \%)$, and a small percentage of particles moved onshore above $50 \mathrm{~m}(<5 \%)$. At the Marguerite Trough intersection, $>50 \%$ of the particles moved onto the shelf at $100 \mathrm{~m}(25 \%)$ and $200 \mathrm{~m}$ (30\%) (Fig. 8D). These particles were derived mostly from the shelf break, the open ocean off Marguerite Bay, or from the outer shelf west of Marguerite Bay (Fig. 8B).
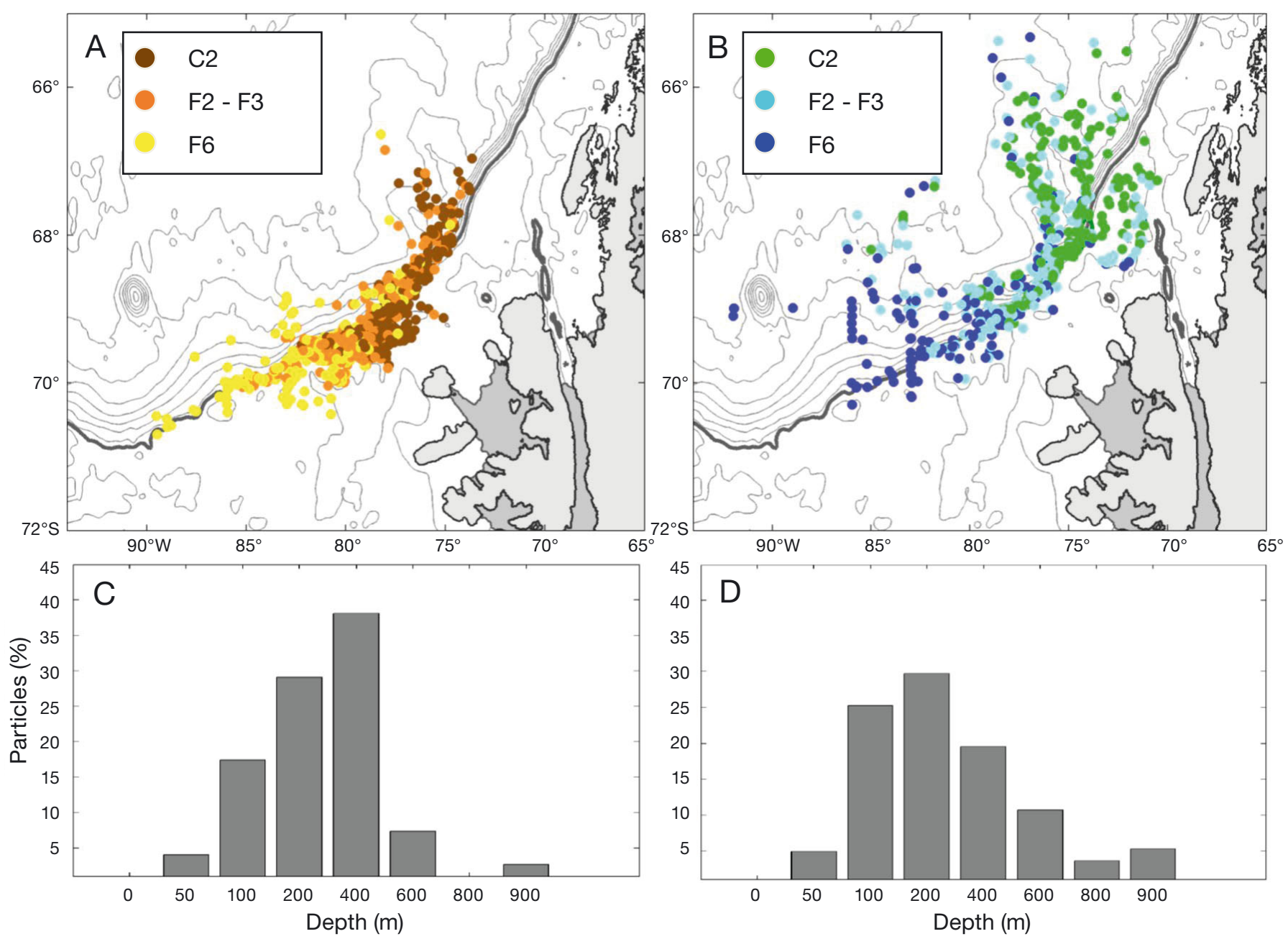

Fig. 8. Distribution of the origination regions for simulated particles that arrived at (A) Alexander Island and (B) Marguerite Trough as calyptopis 2 (C2), furcilia 2 and 3 (F2-F3) and furcilia 6 (F6) larval stages. The particle transit time was converted to larval age or stage using the developmental times given in Table 2 . The percentage of particles at different depths that were transported to the (C) Alexander Island and (D) Marguerite Trough intersections is also shown. The depth intervals used to apportion the particles correspond to those used for net tows made during the US SO GLOBEC field studies 

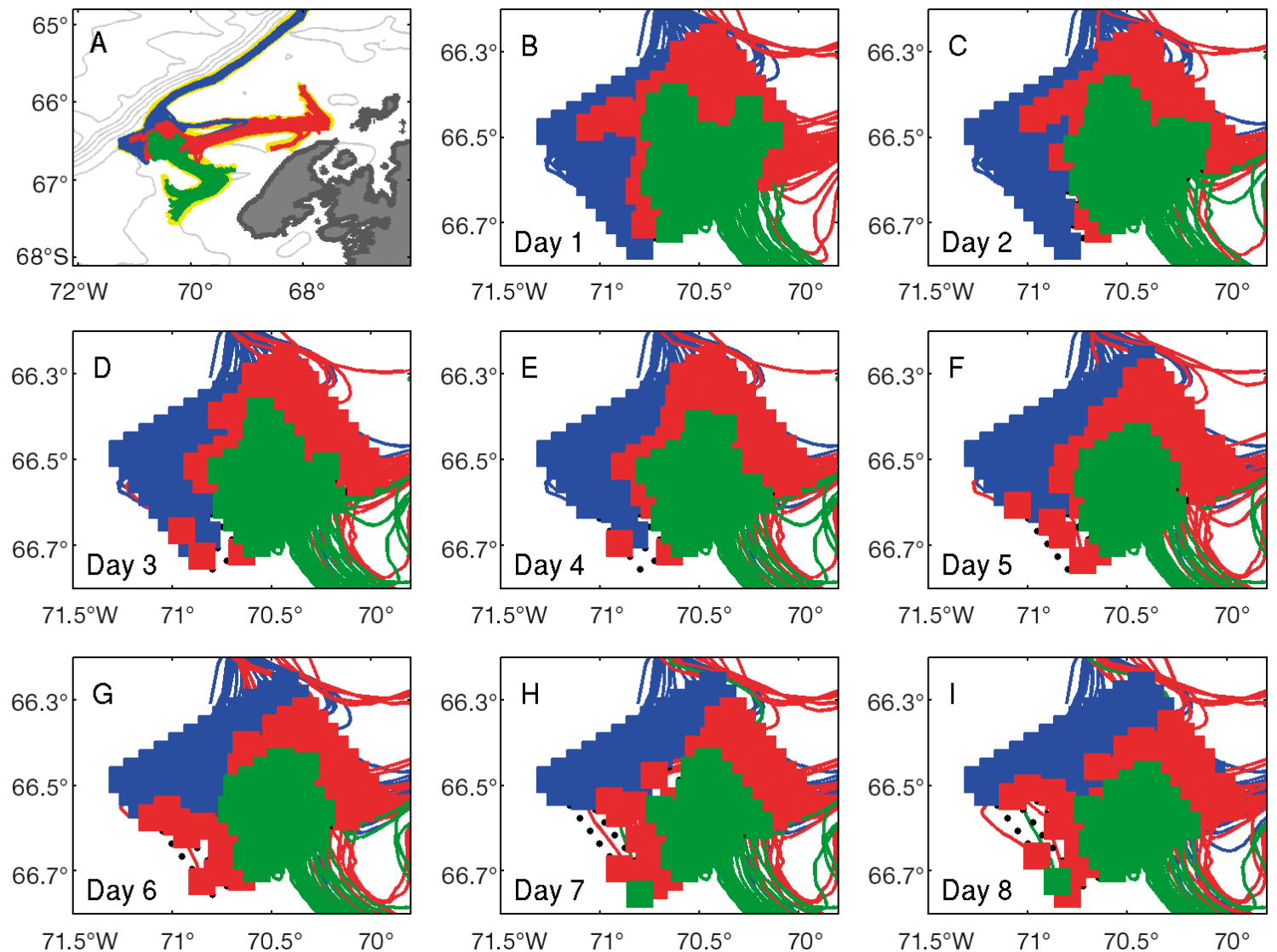

Fig. 9. (A) Horizontal distribution of the 3 dominant transport pathways obtained for particles released at the outer end of Marguerite Trough at $100 \mathrm{~m}$. The difference in the transport pathways that resulted from inclusion of diurnal vertical migration is indicated by the yellow shading. (B-I) Release sites of particles at daily intervals for $8 \mathrm{~d}$. The 3 transport pathways are designated as downstream (blue), on-shelf (red) and Marguerite Trough (green)

\section{Role of Marguerite Trough}

The shelf break and slope off Marguerite Bay has been suggested as a region with local recruitment of Antarctic krill (Daly 2004, Pakhomov et al. 2004). Inputs to this region were investigated by releasing a grid of particles at the intersection of Marquerite Trough and the shelf break (Fig. 9). The larval krill originating in the Bellingshausen Sea were transported to the shelf primarily from depths of 100 to 200 $\mathrm{m}$. Therefore, the time sequence of the horizontal distribution of the transport pathways is shown for particles released at $100 \mathrm{~m}$. Once released, the particles were apportioned into specific pathways determined by the origination point and subsequent transport showed 3 dominant pathways (Fig. 9A). The addition of diurnal vertical migration to the particles did not alter these dominant pathways (Fig. 9A).

The downstream pathway flows along the shelf break to the northeast away from Marguerite Bay and the shelf. The second pathway extends along the Adelaide Island depression and reaches the inner shelf north of Marguerite Bay towards Crystal Sound. The third pathway was along Marguerite Trough towards Marguerite Bay (Fig. 9A). The downstream pathway dominated the west side of the Marguerite Trough region (Fig. 9B-F) and with time also dominated the offshore east side (Fig. 9G-I).

The particles that entered the wAP continental shelf north of Marguerite Bay were mostly from the region east of Marguerite Trough. These particles continued along the depression off Adelaide Island into the mid-shelf region heading towards Crystal Sound, or perhaps continued to the northeast on the shelf. Particles entering Marguerite Bay moved along the east flank of the trough from the center side of the release region (Fig. 9).

The depth distribution of the percentage of particles associated with the 3 dominant pathways differed. The highest percentage of particles followed 
the Marguerite Trough pathway, and the second highest percentage was associated with the on-shelf pathway (Fig. 10). Particles released shallower than $25 \mathrm{~m}$ tended to follow the downstream pathway and be transported to the northeast with the prevailing flow of the ACC. This tendency decreased with depth, especially below $200 \mathrm{~m}$, where only $<20 \%$ of the larvae were transported away from Marguerite Bay (Fig. 10). At $100 \mathrm{~m}$, the percentage of particles that followed any of the 3 dominant pathways was approximately the same. However, only 2 of the 3 pathways provided sources of potential larvae to shelf sites in Marguerite Bay and Crystal Sound (Fig. 9). Below $200 \mathrm{~m}$ there was a tendency for the particles to follow the Marguerite Trough pathway, especially at $300 \mathrm{~m}$, where $\sim 40 \%$ of the total entered the shelf via this pathway (Fig. 10). The percentage of particles that did not follow one of the dominant pathways (Fig. 10) was $<15 \%$ for all depths.

The temporal variability of the transport pathways was determined by releasing particles at daily intervals for $1 \mathrm{mo}$ (Fig. 11). At $25 \mathrm{~m}$ the particles tended to follow the downstream pathway (Fig. 11A), accounting for $>40 \%$ of the particles for 22 of the $32 \mathrm{~d}$. During the other $10 \mathrm{~d}$, including $6 \mathrm{~d}$ at the start of the time series and $4 \mathrm{~d}$ around Day 20, there was a preference for the particles to continue on-shelf along the Adelaide Island depression. During the first $10 \mathrm{~d}$ of the month at $100 \mathrm{~m}$ (Fig. 11B), the particles were as likely to continue along the downstream or on-shelf pathway. However, around Day 12 and at the end of the time series, the downstream pathway dominated (Fig. 11B), similar to that for $200 \mathrm{~m}$ after Day 24

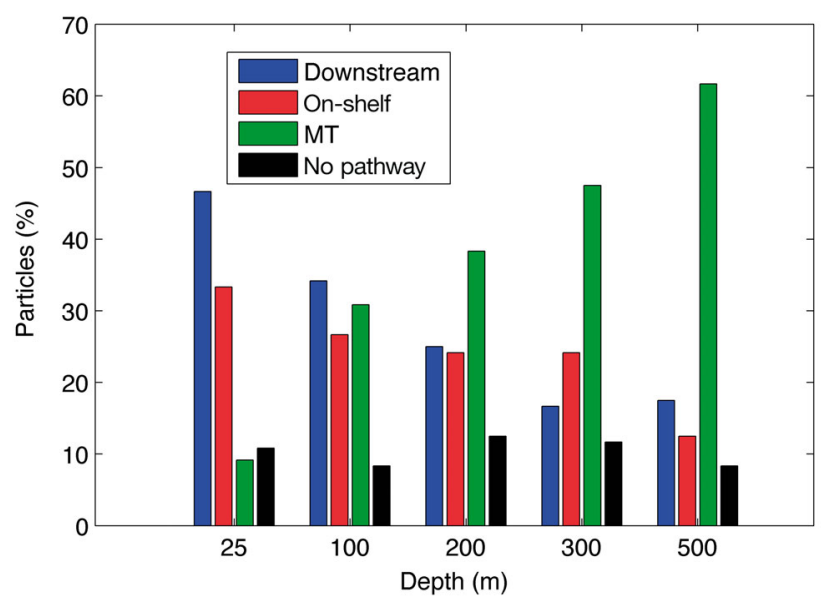

Fig. 10. Depth distribution of the percentage of total particles released along the outer end of Marguerite Trough (MT) that followed the 3 dominant transport pathways and the relative percentage at each depth. The percentage of particles that followed no pathway is also shown
(Fig. 11C). Below $200 \mathrm{~m}$ the Marguerite Trough pathway dominated (Fig. 11C-E) and particle transport at $500 \mathrm{~m}$ (Fig. 11E) was predominantly along the Marguerite Trough pathway.

\section{Local spawning and retention}

Simulated trajectories for particles released on the wAP shelf at a site to the northeast between Renaud and Anvers Island (northernmost box) and at a site to the southwest of Alexander Island (southernmost box) showed that these regions export particles to the north and south and that the particles remain mostly on the shelf (Fig. 12). A proportion of the particles released at a central site just off the western entrance of Marguerite Bay moved across the shelf and entered the northeastward flow of the ACC. Other particles entered Marguerite Bay or moved southward along Alexander Island.

Apportioning the trajectories into times that correspond to the calyptopis 2 larval stage ( $47 \mathrm{~d}$; Fig. $12 \mathrm{~A}, \mathrm{D})$ suggested that these larvae, if spawned on the southern wAP shelf, would be found in Marguerite Bay and along Marguerite Trough. Similarly, spawns to the north would result in calyptopis 2 larvae on the inner shelf west of Renaud Island. Export from the shelf occurred after larvae developed to the furcilia 2 and 3 stages (Fig. 12B,E). Only a small percentage of the larvae crossed the $800 \mathrm{~m}$ isobath and moved offshore before the furcilia 3 stage was completed (Table 5). However, export increased after $150 \mathrm{~d}$, at which point the larvae correspond to the furcilia 6 stage. At $300 \mathrm{~m}$, furcilia 6 larvae coming from the southern portion of the wAP shelf (Fig. 13F) reached the vicinity of Marguerite Bay. However, particles at $100 \mathrm{~m}$ were retained on the mid-shelf, preventing larvae from reaching Marguerite Bay (Fig. 12C).

Particles released at 4 locations along the inner wAP shelf at times that correspond to when spawning occurs (Fig. 13) showed that early in the reproductive season (15 November) export of calyptopis 2 and furcilia 3 larvae was low at the 3 southern-most release sites (Fig. 13A,B). Export of calyptopis 2 larvae occurred only at the northern release site near Anvers Island (Fig. 13A, Table 6). For the 24 December release, the sites off Charcot Island, Adelaide Island and Renaud Island showed essentially no export (Fig. 13D-F). Particles exported from the Charcot Island site were returned to the shelf by the circulation (Table 6). Export of the late-stage larvae exceeded $20 \%$, but only for the northernmost release site. By mid-January, there was some exchange of 

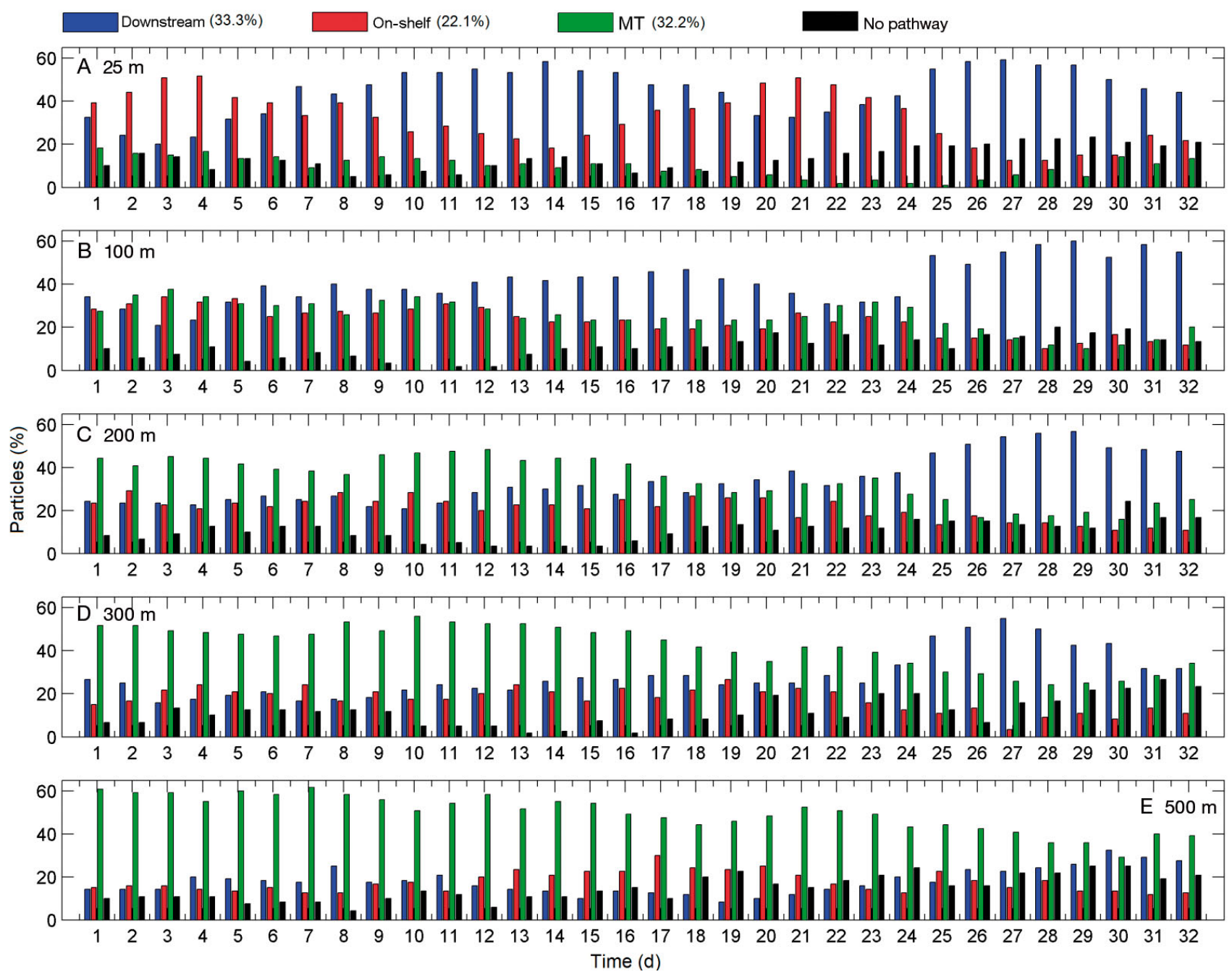

Fig. 11. Time series of the percentage of particles that followed the 3 dominant transport pathways after release at the offshore end of Marguerite Trough (MT) and of those that followed no pathway at (A) $25 \mathrm{~m}$, (B) $100 \mathrm{~m}$, (C) $200 \mathrm{~m}$, (D) $300 \mathrm{~m}$ and (E) $500 \mathrm{~m}$ depth. The percentages were calculated relative to the total number of particles released. Monthly means for all depths for each pathway are also shown

particles between the 3 northern sites, but the southernmost site remained essentially self-contained (Fig. 13G-I, Table 6).

Particle export from the inner shelf sites tended to be to the north along the shelf, but particle exchange between the sites tended to be low (Fig. 14). A small number of individuals from Adelaide Island reached Renaud Island (Fig. 14C,D) and there was limited exchange between Renaud Island and Anvers Island (Fig. 14E,F). The December and January releases showed similar dispersion patterns.

The furcilia 6 larvae from Charcot Island occupied the shelf west of Alexander Island and only a small number of individuals were observed along the shelf northeast of Marguerite Bay (Fig. 14). The release sites near Charcot Island and Adelaide Island showed no direct connectivity (Fig. 14A-D). The Adelaide Island release site showed higher retention and some connectivity with the region near Renaud Island (Fig. 14C,D). The largest number of particles was found either on the mid-shelf north of Marguerite Bay or in the fjords southwest of Anvers Island (Fig. 14C-F). Larvae from the Renaud Island site were observed on the inner wAP shelf and around the Anvers Island release site (Fig. 14E,F).

The number of particles originating near Renaud Island that reached near Anvers Island was low, but dispersion and retention occurred along and between the inner shelf between these 2 areas. Most of the furcilia 6 larvae released near Anvers Island in 

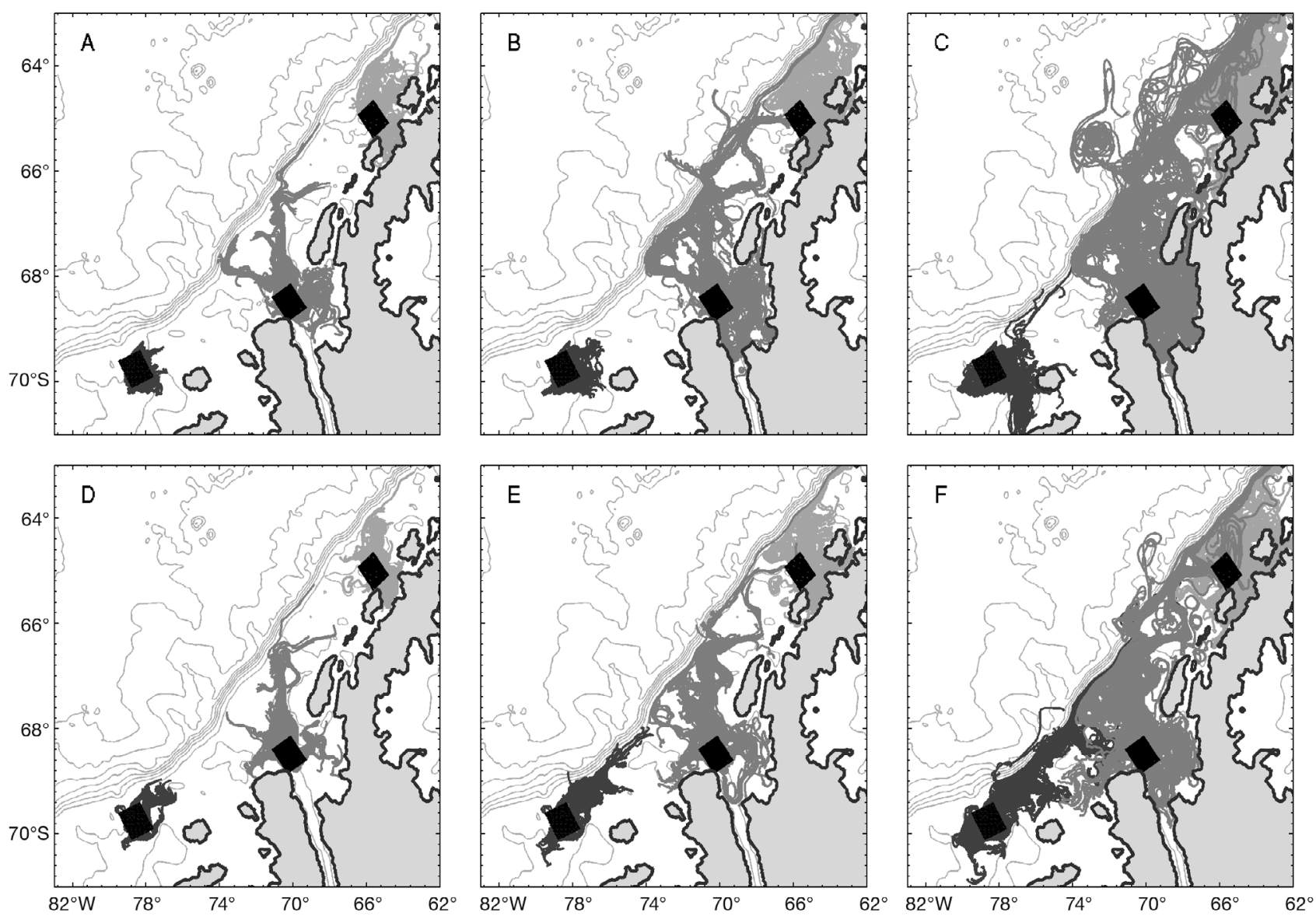

Fig. 12. Dispersion of simulated particles released at $100 \mathrm{~m}(\mathrm{~A}, \mathrm{~B}, \mathrm{C})$ and $300 \mathrm{~m}(\mathrm{D}, \mathrm{E}, \mathrm{F})$ at 3 sites (black boxes) over the western Antarctic Pensinsula continental shelf. The particle transit times were mapped to the (A,D) calyptopis 2, (B,E) furcilia 3 and $(\mathrm{C}, \mathrm{F})$ furcilia 6 larval stages using the developmental times given in Table 2

January were exported from the shelf (Fig. 15H). In contrast, a December release at this site resulted in a larger number of particles being retained north and east of the release site (Fig. 15G).

\section{DISCUSSION}

\section{Western Bellingshausen Sea inputs}

The Lagrangian tracking experiments showed that particles released within the observed high chlorophyll concentration area (Marrari et al. 2008) in the Bellingshausen Sea were entrained in the northnortheastward flowing $\mathrm{ACC}$ and transported along the outer shelf, reaching the wAP shelf in 120-150 d. In areas where the alongshelf flow is deflected onshore, such as Marguerite Trough and the bathymetric depression off Alexander Island, these particles moved onto the wAP continental shelf. The transport time scales correspond to developmental times associated with the early to late larval stages of Antarctic krill. The locations of the on-shelf movement of the krill larval stages in the WAP region are consistent with observed distributions (Siegel 1988, 2000, Ashjian et al. 2004). The transport of particles onto the wAP shelf was to areas where persistent krill densities were observed during fall, such as Crystal Sound and Laubeuf Fjord (Zhou \& Dorland 2004, Ross et al. 2008, Wiebe et al. 2011).

The observations of Antarctic krill distributions from the Bellingshausen Sea and wAP continental shelf support the patterns obtained from the numerical Lagrangian experiments. Acoustic observations of the abundance and distribution of Antarctic krill in the marginal ice zone of the Bellingshausen Sea area showed large krill swarms offshore in the open sea between 84 and $86^{\circ} \mathrm{W}$ south of $67^{\circ} \mathrm{S}$ in an area characterized by mesoscale eddies and high chlorophyll concentrations (> $6 \mathrm{mg} \mathrm{chl} \mathrm{a} \mathrm{m}^{-3}$ ) (Murray et al. 1995, 
Table 5. Percentage of particles released at 50,100, 150 and $300 \mathrm{~m}$ that were exported from the continental shelf from sites on the southern (S), central (C) and northern $(\mathrm{N})$ portions of the western Antarctic Peninsula (see Fig. 1 for site locations). At each site and depth 208 particles were released. The particle transit times were mapped into Antarctic krill larval stage using the developmental times given in Table 2 . The total percent export for each depth and site over 1 yr is given in the last column. See Table 2 for larval stage abbreviations

\begin{tabular}{|c|c|c|c|c|c|c|c|c|c|c|c|}
\hline \multicolumn{2}{|c|}{-Release - } & \multicolumn{10}{|c|}{ - Larval staqe } \\
\hline Area & $\begin{array}{l}\text { Depth } \\
\text { (m) }\end{array}$ & $\mathrm{N} 1-\mathrm{C} 1$ & $\mathrm{C} 2$ & $\mathrm{C} 3$ & F1 & F2 & F3 & $\mathrm{F} 4$ & F5 & F6 & $1 \mathrm{yr}$ \\
\hline $\mathrm{S}$ & 50 & 0 & 0 & 0 & 0 & 0 & 0 & 0 & 1 & 0 & 9 \\
\hline $\mathrm{C}$ & 50 & 0 & 3 & 6 & 13 & 9 & 9 & 10 & 17 & 19 & 47 \\
\hline $\mathrm{N}$ & 50 & 0 & 1 & 1 & 6 & 13 & 18 & 22 & 35 & 44 & 83 \\
\hline $\mathrm{S}$ & 100 & 0 & 0 & 0 & 4 & 5 & 6 & 8 & 8 & 12 & 27 \\
\hline $\mathrm{C}$ & 100 & 0 & 0 & 0 & 2 & 2 & 4 & 4 & 4 & 6 & 32 \\
\hline $\mathrm{N}$ & 100 & 0 & 0 & 3 & 4 & 10 & 14 & 16 & 18 & 25 & 66 \\
\hline $\mathrm{S}$ & 150 & 0 & 0 & 0 & 2 & 3 & 6 & 5 & 8 & 9 & 25 \\
\hline $\mathrm{C}$ & 150 & 0 & 0 & 0 & 0 & 1 & 1 & 1 & 1 & 3 & 19 \\
\hline $\mathrm{N}$ & 150 & 0 & 0 & 1 & 4 & 7 & 10 & 13 & 19 & 25 & 50 \\
\hline $\mathrm{S}$ & 300 & 0 & 0 & 0 & 0 & 1 & 3 & 3 & 3 & 6 & 22 \\
\hline $\mathrm{C}$ & 300 & 0 & 0 & 0 & 2 & 3 & 3 & 4 & 5 & 9 & 39 \\
\hline $\mathrm{N}$ & 300 & 0 & 0 & 1 & 2 & 5 & 10 & 12 & 14 & 19 & 76 \\
\hline
\end{tabular}

Savidge et al. 1995). The area sampled during these studies is consistent with potential spawning grounds inferred from the Lagrangian experiments that resulted in transport of furcilia larvae onto the WAP shelf via Marguerite Trough. Additional netbased observations showed that Antarctic krill size or age groups were spatially segregated along a gradient from the shelf break to offshore waters in the Bellingshausen Sea area during January through March (Siegel \& Harm 1996). Large mature krill size groups were found mostly in open water, and younger krill (age group +1 ) were found near the shelf break and over the southern shelf. Most of the females were in a prespawning or early spawning stage. An analysis of female Antarctic krill from the WAP shelf, including the re-
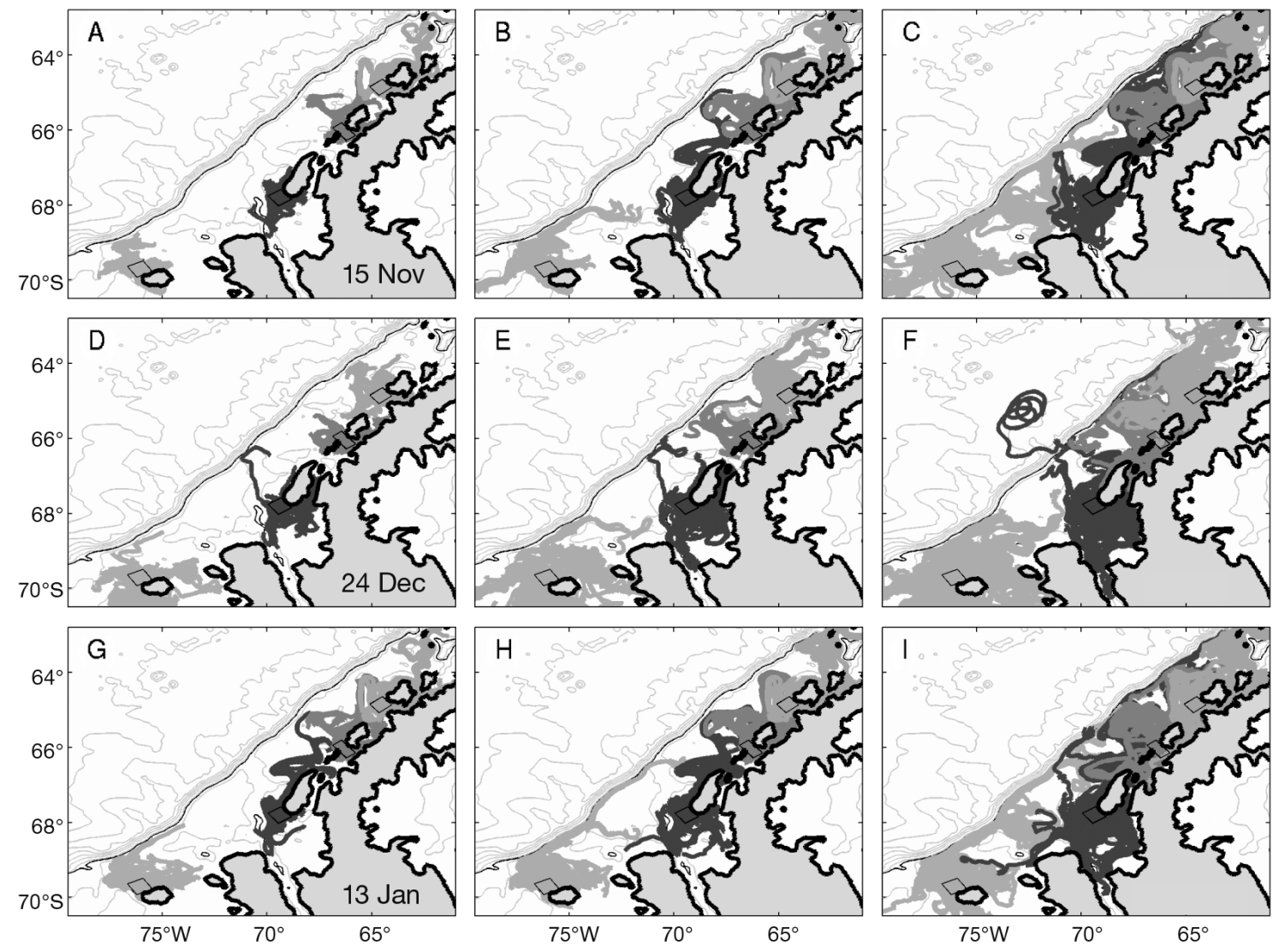

Fig. 13. Distribution of simulated particles released at $50 \mathrm{~m}$ along the inner portion of the wAP continental shelf on (A-C) 15 November, (D-F) 24 December and (G-I) 13 January. The particle transit times were mapped to the (A,D,G) calyptopis 2, $(\mathrm{B}, \mathrm{E}, \mathrm{H})$ furcilia 3 and $(\mathrm{C}, \mathrm{F}, \mathrm{I})$ furcilia 6 larval stages using the developmental times given in Table 2 . The 4 release sites $(\diamond)$ were (from south to north) near Charcot Island, Adelaide Island, Renaud Island and Anvers Island 
Table 6. Percentage of particles released at 25, 50, 100 and $300 \mathrm{~m}$ that were exported from the shelf from sites near Charcot Island $(\mathrm{CH})$, Adelaide Island (AdI), Renaud Island (RI) and Anvers Island (AI). At each site and depth 90 particles were released. The particle transit times were mapped into Antarctic krill larval stage using the developmental times given in Table 2. The total percent export for each depth and site over $1 \mathrm{yr}$ is given in the last column. See Table 2 for larval stage abbreviations

\begin{tabular}{|c|c|c|c|c|c|c|c|c|}
\hline \multicolumn{2}{|c|}{ _ Release $\_$} & \multicolumn{7}{|c|}{ Larval stage- } \\
\hline Area & Depth (m) & $\mathrm{N} 1-\mathrm{F} 1$ & F2 & F3 & F4 & F5 & F6 & $1 \mathrm{yr}$ \\
\hline $\mathrm{CH}$ & 25 & 0 & 0 & 0 & 0 & 0 & 0 & 0 \\
\hline AdI & 25 & 0 & 0 & 0 & 0 & 0 & 0 & 2 \\
\hline RI & 25 & 0 & 0 & 0 & 0 & 0 & 2 & 18 \\
\hline $\mathrm{AI}$ & 25 & 0 & 0 & 6 & 12 & 23 & 38 & 51 \\
\hline $\mathrm{CH}$ & 50 & 0 & 0 & 0 & 0 & 0 & 0 & 0 \\
\hline AdI & 50 & 0 & 0 & 0 & 0 & 0 & 2 & 17 \\
\hline RI & 50 & 0 & 0 & 0 & 0 & 0 & 2 & 17 \\
\hline AI & 50 & 0 & 0 & 3 & 12 & 20 & 31 & 56 \\
\hline $\mathrm{CH}$ & 100 & 0 & 0 & 0 & 0 & 0 & 0 & 0 \\
\hline AdI & 100 & 0 & 0 & 0 & 0 & 0 & 0 & 1 \\
\hline RI & 100 & 0 & 0 & 0 & 0 & 0 & 1 & 17 \\
\hline $\mathrm{AI}$ & 100 & 0 & 0 & 3 & 14 & 26 & 43 & 56 \\
\hline $\mathrm{CH}$ & 300 & 0 & 0 & 0 & 0 & 0 & 0 & 1 \\
\hline AdI & 300 & 0 & 0 & 0 & 0 & 0 & 0 & 3 \\
\hline RI & 300 & 0 & 0 & 0 & 0 & 0 & 0 & 20 \\
\hline AI & 300 & 0 & 1 & 7 & 18 & 24 & 40 & 56 \\
\hline
\end{tabular}

gion around Marguerite Bay, showed an across-shelf separation in maturity stages with pre-spawning females along the inner shelf in regions of high chlorophyll concentrations and gravid females along the outer shelf in regions where CDW was present (Shaw 1997). The simulation results indicated that larvae resulting from spawns that occurred either along the shelf break or on the outer shelf can be transported to the mid and inner regions of the wAP shelf.

Net-based observations from the US SO GLOBEC field studies showed that calytopis 2 to furcilia 2 were the dominant stages of krill larvae between 50 and $200 \mathrm{~m}$ at the outer portion of Marguerite Trough along the shelf break (Daly 2004). Low densities of late-stage furcilia were also present. Additional netbased observations (0-300 m) from the German SO GLOBEC field studies in fall 2001 (Pakhomov et al. 2004) also showed a high abundance of furcilia 1 and 2 over the shelf break and slope around Marguerite Trough. The depth distributions of the simulated particles showed that $\sim 55 \%$ of the particles that arrived at the outer end of Marguerite Trough were in the 100-200 m depth range. The net-based observations from the SO GLOBEC field studies showed that larval krill had maximum densities in the upper $100 \mathrm{~m}$, but at some locations the larvae were distributed over the upper $300 \mathrm{~m}$ (Daly 2004, Pakhomov et al. 2004). Once on the wAP shelf the predominant trans- port pathways moved the particles towards the midshelf through the depression off Adelaide Island to Crystal Sound or through Marguerite Trough to the inner portions of Marguerite Bay (Piñones et al. 2011). These inner shelf sites correspond to biological hotspot regions (Costa et al. 2007).

Marguerite Trough is an important conduit for the on-shelf transport of particles (and larvae) originating in upstream regions. The simulations showed that $40-60 \%$ of the particles that arrived at Laubeuf Fjord were released over the outer portion of Marguerite Trough (intersection of the shelf break with Marguerite Trough) and followed transport pathways along the inner limb of the shelf break and the trough (Piñones et al. 2011). The estimated residence times for inner shelf regions, such as Laubeuf Fjord, were sufficient for the larvae originating in upstream regions to recruit to the shelf krill populations by fall when the seasonal pack-ice closes (Piñones et al. 2011). Observations showed that post-larval krill tend to occupy the inner shelf areas of the wAP late in the fall (Siegel 1988, 2005) and that larvae are more uniformly distributed over the shelf (Ashjian et al. 2004)

The Lagrangian particle experiments also showed that the shelf area west of Alexander Island (around $76^{\circ} \mathrm{W}$ ) is a potential source region of larval krill to the Marguerite Bay region. This is an area where the descent-ascent portion of the krill reproductive cycle can be successfully completed owing to the deep shelf depressions and troughs (Hofmann \& Hüsrevo lu 2003). The particle transport times indicated that this region is a potential spawning area, resulting in calyptopis 2 larvae being transported to the outer portion of Marguerite Trough. Analysis of video plankton recorder data obtained from surveys made during the US SO GLOBEC 2001 field studies showed high abundances of larval euphausiids about the size of a calyptopis 2 on the outer and mid portions of the wAP shelf (Ashjian et al. 2008). Coincident net tows showed that Antarctic krill were the dominant euphausiid species (Wiebe et al. 2011). The observed vertical distribution of larval krill (Ashjian et al. 2008) showed the greatest abundance over the outer shelf and the shelf break, where inputs from the Bellingshausen Sea could supply larvae to the Alexander Island region.

\section{Local spawning and export from the shelf}

Gravid females of Antarctic krill have been observed on mid- to inner-shelf environments in the northern portion of the Antarctic Peninsula (Brinton 

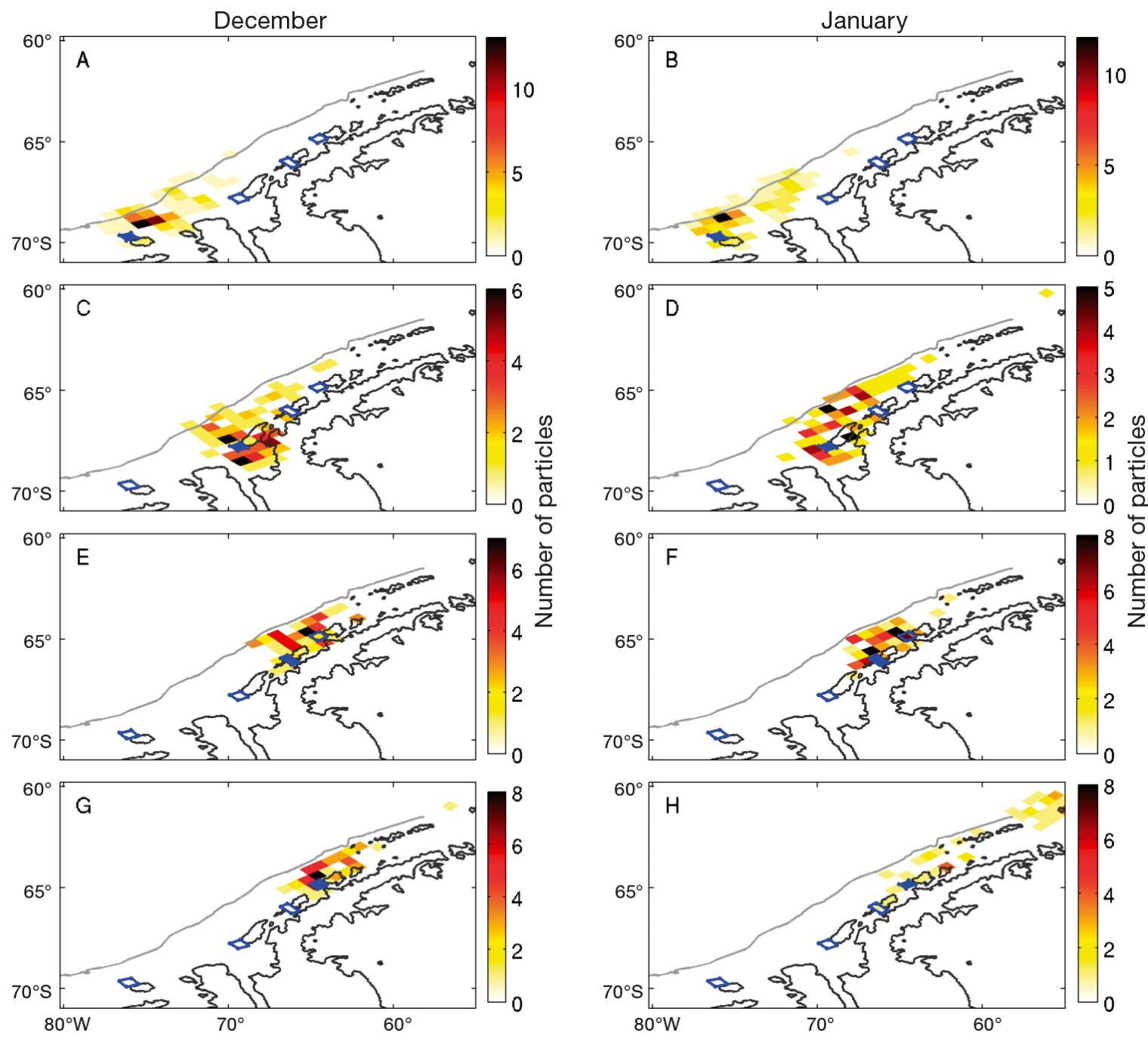

Fig. 14. Distribution of simulated particles released at sites near Charcot Island (A,B), Adelaide Island (C,D), Renaud Island $(E, F)$ and Anvers Island $(G, H)$ along the inner western Antarctic Peninsula shelf in December $(A, C, E, G)$ and January $(B, D, F, H)$. For each region the release site is indicated $(\diamond)$ and the release sites for the other regions $(\diamond)$ are shown for comparison. The number of particles was calculated for $40 \times 40 \mathrm{~km}$ regions of the shelf

1991). From net-based observations, the GerlacheBransfield Strait region was described as a nursery area for early summer larvae. The local circulation was assumed to increase the larval retention times in the nearshore waters that favored continued development and growth (Huntley \& Brinton 1991). The residence time estimated from the particle simulations showed that similar areas of local retention exist in the inner shelf around Marguerite Bay, such as Crystal Sound. Particles released in these regions tended to remain in the vicinity but some export to the surrounding shelf, off-shelf regions and between retention regions occurred. The extent of the exchange along the inner shelf is likely under-represented because the seasonal Antarctic Peninsula coastal current (Moffat et al. 2008) is not adequately repre- sented in the wAP circulation model (Dinniman \& Klinck 2004). However, the retentive nature of the inner-shelf regions provides support for local retention and development of biological hot spots (Costa et al. 2007) and potential hotspots for Antarctic krill recruitment (Pakhomov et al. 2004).

The larval krill distributions (Daly 2004, Wiebe et al. 2011) observed in the Marguerite Bay region during the US SO GLOBEC field studies (Fig. 15) suggested that inputs of Antarctic krill occurred at sites on and off the shelf. Net samples obtained inside Marguerite Bay during fall 2001 and 2002 (Daly 2004) showed high abundances of older stage larvae concentrated in a narrow layer near the surface. Younger larval stages were observed at off-shelf locations. The simulated dispersion of older stage lar- 


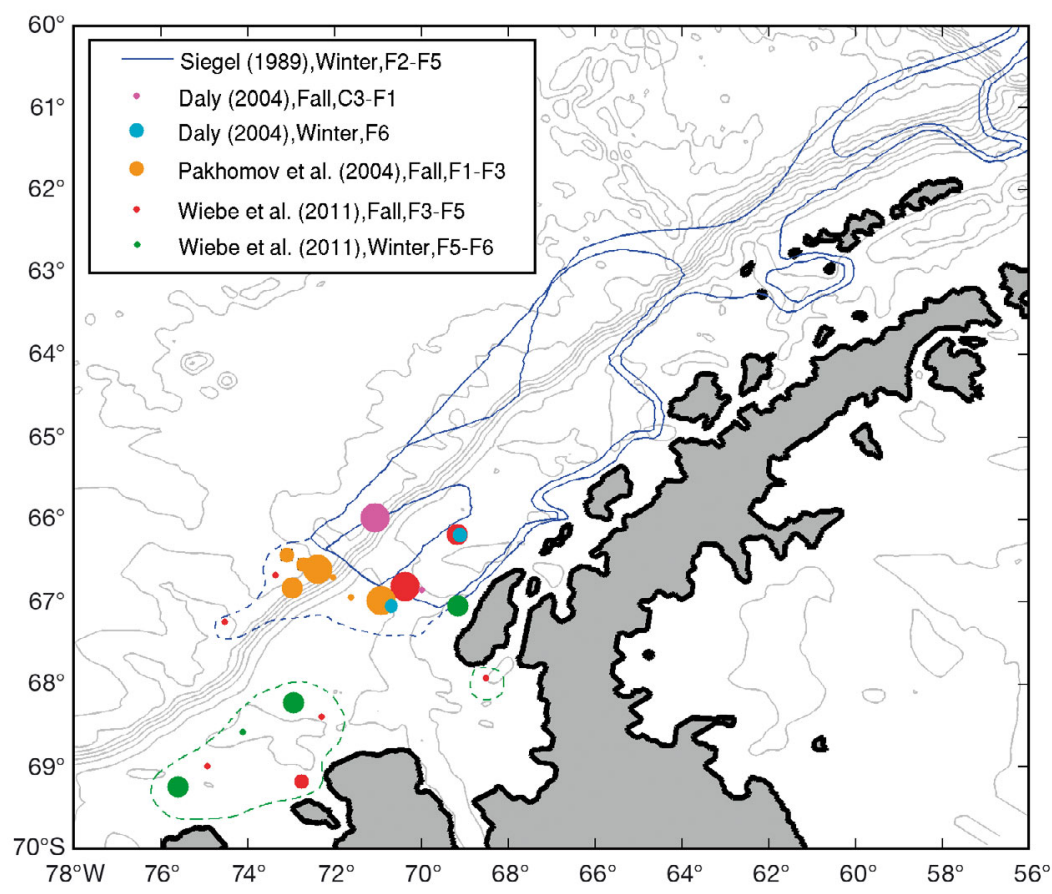

Fig. 15. Climatology of the horizontal distribution of late calyptosis (C3) and furcilia stages (F1-F6) constructed from net-based observations made along the western Antarctic Peninsula continental shelf during fall and winter. The observations from Daly (2004), Pakhomov et al. (2004), and Wiebe et al. (2011) were made during the SO GLOBEC cruises. The observations from Siegel (1989) are from other surveys

vae (furcilia 6) that originated along 4 release locations on the shelf showed distributions similar to the on-shelf observations given by Daly (2004). The numerical experiments suggested that local spawning around Marguerite Bay can provide furcilia 6 larvae to either the mid-shelf north of Adelaide Island or the fjords inside Marguerite Bay. Larval krill hatched from embryos released in summer along the mid and outer shelf north of Marguerite Bay would enter winter as late-stage furcilia larvae (furcilia 6) and occupy the mid and outer shelf region between Adelaide Island and Anvers Island. This simulated distribution is consistent with the winter distribution of older larval stages developed by Siegel (1989) from net-based observations (Fig. 15).

Net-based observations made on the outer wAP shelf during fall 2001 prior to the US SO GLOBEC observations (Fig. 15) showed that furcilia 2 and 3 stages accounted for $60 \%$ of the total larval abundance (Pakhomov et al. 2004). The simulated particles showed that embryos spawned on the shelf developed into furcilia 3 by early fall, thus providing a source of the furcilia 6 larvae observed in late fall.

Ashjian et al. (2004) showed that the greatest abundance and biomass of larval euphausiids on the wAP shelf was associated with a persistent clockwise gyre located to the west of Adelaide Island. This is also the region where simulated particles that correspond to furcilia 6 larvae accumulate. Marrari et al. (2011) and Ashjian et al. (2004) also observed high abundance and biomass of juvenile and adult krill in Laubeuf Fjord during fall 2001. The video plankton recorder observations from the 2001 fall and winter surveys showed larval krill were present across the entire shelf with high abundances at the shelf break (Ashjian et al. 2008). The SO GLOBEC observations are consistent with those made during the Second International BIOMASS Experiment (Siegel 1989), which showed winter distributions of furcilia 3 to furcilia 5 larvae along the wAP continental shelf break and mid shelf (Fig. 15). The highest abundances were towards the area off of Adelaide Island (the southwestern area covered by that survey).

Local spawning does not necessarily imply local retention. The simulated trajectories for particles released at inner-shelf sites north of the Marguerite Bay region showed that older larval krill could be transported as far north as Elephant Island. Several modeling studies have shown that transport of Antarctic krill from the Antarctic Peninsula does occur and that krill populations in downstream regions, such as South Georgia, are sustained by inputs of individuals from the Antarctic Peninsula (Murphy et al. 1998, Fach et al. 2006, Thorpe et al. 2004, 2007).

\section{Implications for wAP krill populations}

The results of the present study suggest that Antarctic krill populations along the outer and mid wAP shelf receive significant ( $23 \%$ as furcilia 6 ) and consistent inputs from upstream sources. The extent to which the wAP populations are dependent on these inputs is likely variable and dependent on season and location. The Lagrangian tracking results from this study showed that particles are transported to particular regions of the WAP with time scales that were consistent with that required for development of an Antarctic krill from an embryo to late furcilia stages (186 d). 
The preferred transport pathways for particles released over Marguerite Trough at the surface and at depth resulted in inputs to inner-shelf regions, such as Crystal Sound. Crystal Sound supports high densities of crabeater seals (Burns et al. 2004). Also, Adélie penguin distributions along the wAP shelf are linked to regions of enhanced krill abundance (Fraser \& Trivelpiece 1996), which is their primary food source. During the SO GLOBEC field studies, Adélie penguins were found near or over Marguerite Trough and in areas associated with CDW (Ribic et al. 2008). Humpback and minke whales distributions on the wAP shelf have a positive relationship with high zooplankton acoustic volume backscatter in the upper and mid water column (Friedlaender et al. 2006). The fact that the observed distributions of these predators coincided with areas in which the simulated particles were retained or areas that received consistent and significant inputs from other regions suggests that these areas promote retention of both larval and adult stages of krill. The implication is that the top trophic level predators target these locations because of access to a dependable food supply (Costa et al. 2007). Thus, the spatial variability in dependence on local versus remote inputs has implications for predators that depend on Antarctic krill as the primary prey.

The Lagrangian particle simulations suggest a scenario that may maintain krill abundances that are needed as prey by the wAP shelf top trophic level predators. Furcilia larvae that arrive in the Marguerite Bay region from other source regions are transported to the inner-shelf areas by the shelf circulation during the late summer and fall. By winter, sea ice covers these regions, providing an overwintering habitat for larval and juvenile krill with sufficient available food (from sea ice) and retention due to local circulation (Piñones et al. 2011). The next summer Krill juveniles (1 yr old) are found in the inner-shelf region. This scenario is supported by krill length-frequency distributions collected in summer, which showed small krill (33 to $37 \mathrm{~mm}$ ) throughout the inner-shelf region of the wAP between Anvers Island and Renaud Island (Lascara et al. 1999). Krill >40 mm were restricted to the outer shelf. Summer size compositions of Antarctic krill collected in deeper shelf waters $(140 \mathrm{~m})$ between Renaud Island and Adelaide Island showed length classes that ranged from 18 to $27 \mathrm{~mm}$ with a modal value of $22 \mathrm{~mm}$ (Siegel 1985). These individuals were categorized as small juveniles and accounted for $91 \%$ of the total individuals that were sampled.
The occurrence of juvenile and medium-size krill along the inner shelf may result from local inputs in areas of the shelf where the shelf is deep (Brinton 1991, Hofmann et al. 1992) and CDW is present, which allows completion of the descent-ascent cycle (Hofmann \& Hüsrevo lu 2003). The clockwise surface circulation over the shelf and onshore flow at depth (Stein 1992, Smith et al. 1999, Dinniman \& Klinck 2004) may facilitate transport of krill larvae to the inner shelf.

Spawning of gravid female krill along the wAP continental shelf break contributes to the transport of larval krill to downstream areas by the ACC (Hofmann et al. 1992, Fach et al. 2002, Thorpe et al. 2004, 2007). For example, 40\% (25 to $100 \mathrm{~m}$ ) and 20\% (below $200 \mathrm{~m}$ ) of the particles released along the outer part of Marguerite Trough were transported northeast away from Marguerite Bay. The particle simulations also showed considerable across-shelf transport, which potentially provides inputs from the inner and mid shelf to downstream regions as well as to other areas of the wAP shelf. The Bransfield Strait region supports a high krill biomass and is an area of krill reproduction, spawning and recruitment (Brinton 1991, Hofmann et al. 1992, Ichii et al. 1998). The wAP shelf region south of Bransfield Strait has high krill biomass in all seasons (Lascara et al. 1999). The Lagrangian simulations showed that particles released in the Marguerite Bay region can provide inputs to the wAP shelf area south of Bransfield Strait. An earlier particle tracking study (Capella et al. 1992) showed that particles released on the northern part of the wAP shelf also were transported to Bransfield Strait. Thus, krill populations that extend from the southern wAP to Bransfield Strait are connected.

The simulated trajectories showed that $>30 \%$ of the particles originating on the wAP shelf are exported from the shelf and that many of these reach Elephant Island when completing the furcilia 6 stage. Of the 1-yr old krill produced between Renaud Island and Adelaide Island, $\sim 70 \%$ were exported from the wAP shelf and can potentially continue transport across the Scotia Sea.

\section{Remote and local circulation effects}

The transport pathways obtained from the Lagrangian particle simulations show 2 mechanisms by which the ocean circulation provides Antarctic krill larvae to the wAP continental shelf (Fig. 16). The first results from interactions between the southern 
boundary of the ACC as it flows along the shelf break and the shelf bathymetry, which produce CDW intrusions (Dinniman \& Klinck 2004). The on-shelf flow associated with the intrusions transports krill larvae from the outer shelf to the mid- and inner-shelf regions. Marguerite Trough is a primary site for CDW intrusions and on-shelf transport of krill larvae. Other deep depressions along the wAP shelf edge also provide conduits for the intrusions and sites for on-shelf transport of krill larvae (Fig. 16). Of the simulated particles that originated in the Bellingshausen Sea, $25 \%$ were entrained in intrusions and transported across the shelf to the Marguerite Bay region, providing a mechanism that connects krill populations on the wAP shelf to upstream source populations (Fig. 16). The remaining $75 \%$ of the larvae continued transport to northern areas of the wAP continental shelf, such as near Anvers Island, and potentially across the Scotia Sea (Fig. 16). Thus, on-shelf trans-

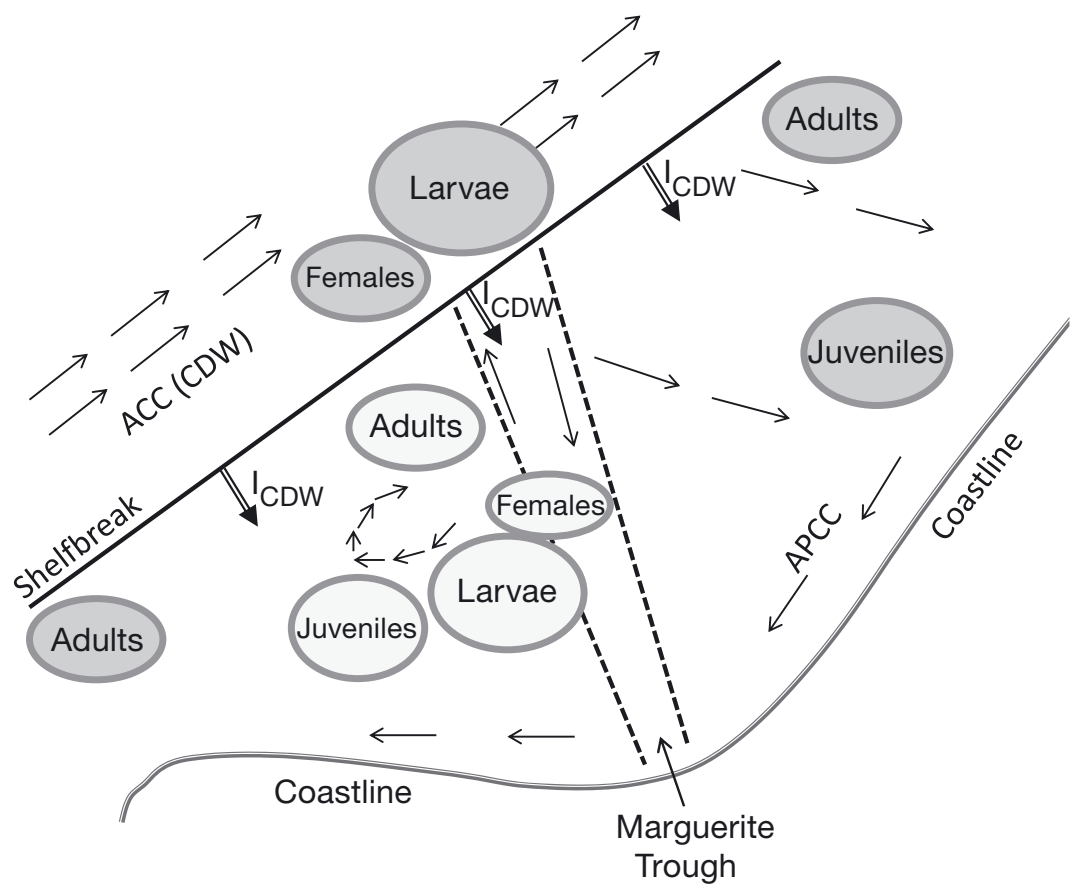

Fig. 16. Conceptual diagram illustrating remote and local connectivity of Antarctic krill populations along the western Antarctic Peninsula (wAP) continental shelf. The Antarctic Circumpolar Current (ACC), which flows along the shelf edge, transports Circumpolar Deep Water (CDW) and Antarctic krill larvae that originated in upstream source regions. On-shelf intrusions of CDW ( $\mathrm{I}_{\mathrm{CDW}}$ ) occur at specific sites, such as Marguerite Trough, and bring larvae onto the shelf. Spawning areas (designated by 'Females') occur along the shelf edge and on the shelf, both of which provide additional larvae. Local retention regions produced by the shelf circulation retain larvae and juveniles that are produced on the wAP shelf (light grey ovals). Transport of larvae to the mid and inner shelf provides a source for the juvenile krill populations in these areas. The Antarctic Peninsula Coastal Current (APCC) potentially provides exchanges along the inner shelf port of larvae at other intrusion sites provides some degree of connectivity of krill populations throughthe wAP shelf to upstream populations. ported to or spawned at the intersection of Marguerite Trough and the wAP shelf break, $54 \%$ moved onto the shelf and were transported to inner-shelf regions that support high biological production, such as the sites in Crystal Sound and off Alexander Island Fig. 16). These larvae provide a source for the juvekrill populations along the mid- and inner-shelf (Fig. 15). regions along the mid and inner shelf (Fig. 16), which provides the second mechanism by which the circulation provides krill larvae to the region. The simulated particle trajectories showed low export from these retention areas, $<20 \%$ for sites south of Renaud Island and $\sim 40 \%$ for Anvers Island. These retention areas allow krill larvae brought in from other areas to complete development, which supports the observed distribution of juveniles along mid- and inner-shelf regions (Fig. 15). The retention regions are also areas where conditions favor successful completion of reproduction by adult Antarctic krill (Hofmann \& Hüsrevoğlu 2003), thereby providing additional larvae to the local krill populations.

The conceptual diagram developed for the transport and retention of the early life stages of Antarctic krill along the wAP continental shelf (Fig. 16) potentially applies to other regions of the Antarctic continental shelf that have similar circulation and hydrographic structure. Prézelin et al. (2000) suggested that regions of high Antarctic krill concentrations were associated with areas where the southern boundary of the ACC was located along the shelf edge. This qualitative comparison suggests that the interaction between remote and local inputs in maintaining Antarctic krill populations along the wAP continental shelf may operate at a circumpolar scale. 
Acknowledgements. This research was funded by National Science Foundation Grant ANT-0523172 and is part of the US Southern Ocean GLOBEC Program synthesis and integration phase. Comments provided by four anonymous reviewers were helpful in clarifying the results from this study.

\section{LITERATURE CITED}

Abramowitz M, Stegun IA (1964) Handbook of mathematical functions with formulas, graphs, and mathematical tables. Tenth Printing AMS IA-National Bureau of Standards Applied Mathematics Series. Washington, DC, Vol 55, $1046 \mathrm{p}$

> Ashjian CJ, Rosenwaks GA, Wiebe PH, Davis CS and others (2004) Distribution of zooplankton on the continental shelf off Marguerite Bay, Antarctic Peninsula, during Austral Fall and Winter, 2001. Deep-Sea Res II 51: 2073-2098

> Ashjian CJ, Davis CS, Gallager SM, Wiebe PH, Lawson GL (2008) Distribution of larval krill and zooplankton in association with hydrography in Marguerite Bay, Antarctic Peninsula, in austral fall and winter 2001 described using the Video Plankton Recorder. Deep-Sea Res II 55: $455-471$

Atkinson A, Siegel V, Pakhomov EA, Rothery P (2004) Longterm decline in krill stock and increase in salps within the Southern Ocean. Nature 432:100-103

Batta-Lona PG, Bucklin A, Wiebe PH, Patarnello T, Copley NJ (2011) Population genetic variation of the Southern Ocean krill, Euphausia superba, in the Western Antarctic Peninsula region based on mitochondrial single nucleotide polymorphisms (SNPs). Deep-Sea Res II 58: 1652-1661

Bolmer ST (2008) A note on the development of the bathymetry of the continental margin west of the Antarctic Peninsula from $65^{\circ}$ to $71^{\circ} \mathrm{S}$ and $65^{\circ}$ to $78^{\circ} \mathrm{W}$. Deep-Sea Res II 55:271-276

Brinton E (1991) Distribution and population structure of immature and adult Euphausia superba in the western Bransfield Strait region during the 1986-1987 summer. Deep-Sea Res 38:1169-1193

Budgell WP (2005) Numerical simulation of ice-ocean variability in the Barents Sea region. Ocean Dyn 55:370-387

Burns JM, Costa DP, Fedak MA, Hindell MA and others (2004) Winter habitat use and foraging behavior of crabeater seals along the western Antarctic Peninsula. Deep-Sea Res II 51:2279-2303

Capella JE, Quetin LB, Hofmann EE, Ross RM (1992) Models of the early life history of Euphausia superba - Part II. Lagrangian calculations. Deep-Sea Res 39:1201-1220

Carton JA, Giese BA (2008) A reanalysis of ocean climate using SODA. Mon Weather Rev 136:2999-3017

Costa DP, Burns JM, Chapman EW, Hildebrand J and others (2007) US SO GLOBEC Predator Programme. GLOBEC Int Newsl 13:62-66

Daly KL (1990) Overwintering development, growth, and feeding of larval Euphausia superba in the Antarctic marginal ice zone. Limnol Oceanogr 35:1564-1576

> Daly KL (2004) Overwintering growth and development of larval Euphausia superba: an interannual comparison under varying environmental conditions west of the Antarctic Peninsula. Deep-Sea Res II 51:2139-2168

Deibel D, Daly KL (2007) Zooplankton processes in Arctic and Antarctic polynyas. In: Smith WO, Barber D (eds)
Polynyas: windows into polar oceans. Elsevier Oceanography Series 74:271-322

> Dinniman MS, Klinck JM (2004) A model study of circulation and cross-shelf exchange on the west Antarctic Peninsula continental shelf. Deep-Sea Res II 51: 2003-2022

> Dinniman MS, Klinck JM, Smith WO (2007) Influence of sea ice cover and icebergs on circulation and water mass formation in a numerical circulation model of the Ross Sea, Antarctica. J Geophys Res 112(C11013):1-13

Dinniman MS, Klinck JM, Smith WO (2011) A model study of circumpolar deep water on the west Antarctic Peninsula and Ross Sea continental shelves. Deep-Sea Res II 58:1508-1523

Fach BA, Hofmann EE, Murphy EJ (2002) Modeling studies of Antarctic krill Euphausia superba survival during transport across the Scotia Sea. Mar Ecol Prog Ser 231:187-203

> Fach BA, Hofmann EE, Murphy EJ (2006) Transport of Antarctic krill (Euphausia superba) across the Scotia Sea. Part II: Krill growth and survival. Deep-Sea Res I 53: 1011-1043

Fraser FG (1936) On the development and distribution of the young stages of krill (Euphausia superba). Discovery Rep 14:1-192

> Fraser WR, Hofmann EE (2003) A predator's perspective on causal links between climate change, physical forcing and ecosystem response. Mar Ecol Prog Ser 265:1-15

Fraser WR, Trivelpiece WZ (1996) Factors controlling the distribution of seabirds: winter-summer heterogeneity in the distribution of Adélie penguin populations. In: Ross RM, Hofmann EE, Quetin LB (eds) Foundations for ecological research west of the Antarctic Peninsula. Antarctic Research Series Vol 70. American Geophysical Union, Washington, DC, p 257-272

Frazer TK, Quetin LB, Ross RM (2002) Abundance, sizes and developmental stages of larval krill, Euphausia superba, during winter in ice-covered seas west of the Antarctic Peninsula. J Plankton Res 24:1067-1077

Friedlaender AS, Halpin PN, Qian SS, Lawson GL, Wiebe PH, Thiele D, Read AJ (2006) Whale distribution in relation to prey abundance and oceanographic processes in shelf waters of the Western Antarctic Peninsula. Mar Ecol Prog Ser 317:297-310

Haidvogel DB, Arango H, Budgell WP, Cornuelle BD and others (2008) Ocean forecasting in terrain-following coordinates: formulation and skill assessment of the Regional Ocean Modeling System. J Comput Phys 227: 3595-3624

Hamming RW (1973) Numerical methods for scientists and engineers, 2nd edn. McGraw-Hill, New York, p 721

> Hofmann EE, Hüsrevo lu YS (2003) A circumpolar modeling study of habitat control of Antarctic krill (Euphausia superba) reproductive success. Deep-Sea Res II 50: 3121-3142

> Hofmann EE, Lascara CM (2000) Modeling the growth dynamics of Antarctic krill Euphausia superba. Mar Ecol Prog Ser 194:219-231

> Hofmann EE, Capella JE, Ross RM, Quetin LB (1992) Models of the early life history of Euphausia superba-Part I. Time and temperature dependence during the descentascent cycle. Deep-Sea Res 39:1177-1200

Hofmann EE, Klinck JM, Locarini RA, Fach BA, Murphy EJ (1998) Krill transport in the Scotia Sea and environs. Antarct Sci 10:406-415

Hunter JR, Craig PD, Phillips HE (1993) On the use of ran- 
dom walk models with spatially variable diffusivity. J Comput Phys 106:366-376

> Huntley ME, Brinton E (1991) Mesoscale variation in growth and early development of Euphausia superba Dana in the western Bransfield Strait region. Deep-Sea Res 38: 1213-1240

Ichii T, Katayama K, Obitsu N, Ishii H, Naganobu M (1998) Occurrence of Antarctic krill (Euphausia superba) concentrations in the vicinity of the South Shetland Islands: relationship to environmental parameters. Deep-Sea Res I 45:1235-1262

> Ikeda T (1984) Development of the larvae of the Antarctic krill (Euphausia superba Dana) observed in the laboratory. J Exp Mar Biol Ecol 75:107-117

> Ikeda T, Dixon P (1982) Body shrinkage as a possible overwinter mechanism of the Antarctic krill, Euphausia superba Dana. J Exp Mar Biol Ecol 62:143-151

> Klinck JM, Hofmann EE, Beardsley RC, Saliho lu B, Howard S (2004) Water-mass properties and circulation on the west Antarctic Peninsula continental shelf in austral fall and winter 2001. Deep-Sea Res II 51:1925-1946

> Lascara CM, Hofmann EE, Ross RM, Quetin LB (1999) Seasonal variability in the distribution of Antarctic krill, Euphausia superba, west of the Antarctic Peninsula. Deep-Sea Res I 46:951-984

> Lawson GL, Wiebe PH, Ashjian CJ, Stanton TK (2008a) Euphausiid distribution along the western Antarctic Peninsula - Part B: Distribution of euphausiid aggregations and biomass, and associations with environmental features. Deep-Sea Res II 55:432-454

> Lawson GL, Wiebe PH, Stanton TK, Ashjian CJ (2008b) Euphausiid distribution along the western Antarctic Peninsula-Part A: Development of robust multi-frequency acoustic techniques to identify euphausiid aggregations and quantify euphausiid size, abundance, and biomass. Deep-Sea Res II 55:412-431

Lythe MB, Vaughan DB, the BEDMAP Consortium (2001) BEDMAP: A new ice thickness and subglacial topographic model of Antarctica. J Geophys Res 106:11335-11351 doi: 10.1029/2000JB900449

Marr JWS (1962) The natural history and geography of the Antarctic krill Euphausia superba Dana. Discovery Rep 32:37-465

Marrari M, Daly KL, Hu C (2008) Spatial and temporal variability of SeaWiFS chlorophyll a distributions west of the Antarctic Peninsula: implications for krill production. Deep-Sea Res II 55:377-392

> Marrari M, Daly KL, Timonin A, Semenova T (2011) The zooplankton of Marguerite Bay, Western Antarctic Peninsula. Part I: abundance, distribution, and population response to variability in environmental conditions. Deep-Sea Res II 58:1599-1613

Marschall HP (1983) Sinking speed, density and size of euphausiid eggs. Meeresforschung 30:1-9

> Martinson DG, McKee DC (2012) Transport of warm Upper Circumpolar Deep Water onto the western Antarctic Peninsula continental shelf. Ocean Sci 8:433-442

Maslanyj MP (1987) Seismic bedrock depth measurements and the origin of George VI Sound, Antarctic Peninsula. Br Antarct Surv Bull 75:51-65

> Moffat C, Beardsley RC, Owens B, van Lipzig N (2008) A first description of the Antarctic Peninsula Coastal Current. Deep-Sea Res II 55:277-293

Moffat C, Owens B, Beardsley RC (2009) On the characteristics of Circumpolar Deep Water Intrusions to the west
Antarctic Peninsula Continental Shelf. J Geophys Res 114:C05017 doi:10.1029/2008JC004955

Murphy EJ, Watkins JL, Reid K, Trathan PN and others (1998) Interannual variability of the South Georgia marine ecosystem: biological and physical sources of variation in the abundance of krill. Fish Oceanogr 7:381-390

Murray AW, Watkins JL, Bone DG (1995) A biological acoustic survey in the marginal ice-edge zone of the Bellingshausen Sea. Deep-Sea Res II 42:1159-1175

Nast F (1978) The vertical distribution of larval and adult krill (Euphausia superba Dana) on a time station of Elephant Island, South Shetlands. Meeresforschung 27: 103-118

> Nicol S (2006) Krill, currents, and sea ice: Euphausia superba and its changing environment. Bioscience 56:111-120

Orsi AH, Whitworth T III, Nowlin WD Jr (1995) On the meridional extent and fronts of the Antarctic Circumpolar Current. Deep-Sea Res I 42:641-673

Padman L, Fricker HA, Coleman R, Howard S, Erofeeva L (2002) A new tide model for the Antarctic ice shelves and seas. Ann Glaciol 34:247-254

Pakhomov EA, Atkinson A, Meyer B, Oettl B, Bathmann U (2004) Daily rations and growth of larval krill Euphausia superba in the eastern Bellingshausen Sea during austral autumn. Deep-Sea Res II 51:2185-2198

Piñones A, Hofmann EE, Dinniman MS, Klinck JM (2011) Lagrangian simulation of transport pathways and residence times along the western Antarctic Peninsula. Deep-Sea Res II 58:1524-1539

> Powers JG, Monaghan AJ, Cayette AM, Bromwich DH, Kuo Y, Manning KW (2003) Real - Time mesoscale modeling over Antarctica: The Antarctic Mesoscale Prediction System. Bull Am Meteorol Soc 84:1533-1545

Prézelin BB, Hofmann EE, Mengelt C, Klinck JM (2000) The linkage between Upper Circumpolar Deep Water (UCDW) and phytoplankton assemblages on the west Antarctic Peninsula continental shelf. J Mar Res 58: 165-202

Quetin LB, Ross RM (1984a) School composition of the Antarctic krill Euphausia superba in the waters west of the Antarctic peninsula in the austral summer of 1982. J Crustac Biol 4:96-106

> Quetin LB, Ross RM (1984b) Depth distribution of developing Euphausia superba embryos, predicted from sinking rates. Mar Biol 79:47-53

Quetin LB, Ross RM (1991) Behavioral and physiological characteristics of the Antarctic krill, Euphausia superba. Am Zool 31:49-63

Quetin LB, Ross RM (2003) Episodic recruitment in Antarctic krill Euphausia superba in the Palmer LTER study region. Mar Ecol Prog Ser 259:185-200

Ribic CA, Chapman EW, Fraser WR, Lawson GL, Wiebe PH (2008) Top predators in relation to bathymetry, ice and krill during austral winter in Marguerite Bay, Antarctica. Deep-Sea Res II 55:485-499

> Ross RM, Quetin LB (1986) How productive are Antarctic krill? Bioscience 36:264-269

Ross RM, Quetin LB (1991) Ecological physiology of larval euphausiids, Euphausia superba (Euphausiaceae). Mem Queensl Mus 31:321-333

Ross RM, Quetin LB, Kirsch E (1988) Effect of temperature on development times and survival of early larval stages of Euphausia superba Dana. J Exp Mar Biol Ecol 121:55-71

Ross RM, Quetin LB, Lascara CM (1996) Distribution of Antarctic krill and dominant zooplankton west of the Antarc- 
tic Peninsula. In: Ross RM, Hofmann EE, Quetin LB (eds) Foundations for Ecological Research West of the Antarctic Peninsula, AGU Antarctic Research Series. American Geophysical Union, Washington, DC, p 199-217

Ross RM, Quetin LB, Martinson DG, Iannuzzi RA, Stammerjohn SE, Smith RC (2008) Palmer LTER: Patterns of distribution of five dominant zooplankton species in the epipelagic zone west of the Antarctic Peninsula, 19932004. Deep-Sea Res II 55:2086-2105

Savidge G, Harbour D, Gilpin LC, Boyd PW (1995) Phytoplankton distributions and production in the Bellingshausen Sea, Austral spring 1992. Deep-Sea Res II 42: 1201-1224

Shaw CT (1997) Effect of sea ice conditions on physiological maturity of female Antarctic krill (Euphausia superba Dana) west of the Antarctic Peninsula. MSc thesis, University of California, Santa Barbara

Shchepetkin AF, McWilliams JC (2009) Correction and commentary for 'Ocean forecasting in terrain-following coordinate: Formulation and skill assessment of the regional ocean modeling system' by Haidvogel et al. J. Comp. Phys. 227, pp. 3595-3624. J Comput Phys 228:8985-9000 doi:10.1016/j.jcp.2009.09.002

Siegel V (1985) The distribution pattern of krill, Euphausia superba west of the Antarctic Peninsula in February 1982. Meeresforschung 30:292-305

Siegel V (1988) A concept of seasonal variation of krill (Euphausia superba) distribution and abundance east of the Antarctic Peninsula. In: Sahrhage D (ed) Antarctic Ocean and Resources Variability. Springer, Berlin, p 219-230

Siegel V (1989) Winter and spring distribution and status of the krill stock in Antarctic Peninsula waters. Arch FischWiss 39:45-72

Siegel V (1992) Assessment of the krill (Euphausia superba) spawning stock off the Antarctic Peninsula. Arch FischWiss 41:101-130

Siegel V (2000) Krill demography and variability in abundance and distribution. Can J Fish Aquat Sci 57:151-167

Siegel V (2005) Distribution and population dynamics of Euphausia superba: summary of recent findings. Polar Biol 29:1-22

Siegel V, Harm U (1996) The composition, abundance, biomass and diversity of the epipelagic zooplankton communities of the southern Bellingshausen Sea (Antarctic) with special reference to krill and salps. Arch Fish Mar Res 44:115-139

Editorial responsibility: Christine Paetzold, Oldendorf/Luhe, Germany
Siegel V, de la Mare WK, Loeb V (1997) Long-term monitoring of krill recruitment and abundance indices in the Elephant Island area (Antarctic Peninsula). CCAMLR Sci 4: $19-35$

Siegel V, Loeb V, Gröger J (1998) Krill (Euphausia superba) density, proportional and absolute recruitment and biomass in the Elephant Island region (Antarctic Peninsula) during the period 1977 to 1997. Polar Biol 19:393-398

> Smith WH, Sandwell DT (1997) Global sea floor topography from satellite altimetry and ship depth soundings. Science 277:1956-1962

> Smith DA, Hofmann EE, Klinck JM, Lascara CM (1999) Hydrography and circulation of the West Antarctic Peninsula Continental Shelf. Deep-Sea Res I 46:925-949

Spiridonov VA (1995) Spatial and temporal variability in reproductive timing of Antarctic krill (Euphausia superba Dana). Polar Biol 15:161-174

Stein M (1992) Variability of local upwelling off the Antarctic Peninsula 1986-1990. Arch FischWiss 41:131-158

Thorpe SE, Heywood KJ, Stevens DP, Brandon MA (2004) Tracking passive drifters in a high resolution ocean model: implications for interannual variability of larval krill transport to South Georgia. Deep-Sea Res I 51: 909-920

Thorpe SE, Murphy E, Watkins J (2007) Circumpolar connections between Antarctic krill (Euphausia superba Dana) populations: investigating the roles of ocean and sea ice transport. Deep-Sea Res I 54:792-810

Visser AW (1997) Using random walk models to simulate the vertical distribution of particles in a turbulent water column. Mar Ecol Prog Ser 158:275-281

Wiebe PH, Ashjian CJ, Lawson GL, Piñones A, Copley NJ (2011) Horizontal and vertical distribution of euphausiid species on the Western Antarctic Peninsula US GLOBEC Southern Ocean study site. Deep-Sea Res II 58: 1630-1651

Witek Z, Koronkiewicz A, Soszka GJ (1980) Certain aspects of the early life history of krill Euphausia superba Dana (Crustacea). Pol Polar Res 1:97-115

> Zhou M, Dorland RD (2004) Aggregation and vertical migration behavior of Euphausia superba. Deep-Sea Res II 51: 2119-2137

> Zhou M, Zhu Y, Peterson JO (2004) In situ growth and mortality of mesozooplankton during the austral fall and winter in Marguerite Bay and its vicinity. Deep-Sea Res II 51:2099-2118

Submitted: June 15, 2012; Accepted: January 9, 2013 Proofs received from author(s): April 15, 2013 